Article

\title{
Synthesis and Evaluation of Novel 2-Pyrrolidone-Fused (2-Oxoindolin-3-ylidene)methylpyrrole Derivatives as Potential Multi-Target Tyrosine Kinase Receptor Inhibitors
}

\author{
Ting-Hsuan Yang ${ }^{1}$, Chun-I Lee ${ }^{2}$, Wen-Hsin Huang ${ }^{2}$ and An-Rong Lee ${ }^{1,2, *}$ \\ 1 Graduate Institute of Medical Sciences, National Defense Medical Center, No. 161, Section 6, \\ Mingchuan East Road, Taipei 11490, Taiwan; taffw@gmail.com \\ 2 School of Pharmacy, National Defense Medical Center, No. 161, Section 6, Mingchuan East Road, \\ Taipei 11490, Taiwan; acirlee@gmail.com (C.-I.L.); wenhsin@ndmctsgh.edu.tw (W.-H.H.) \\ * Correspondence: 416806@gmail.com; Tel.: +886-2-8792-3100 (ext. 18873)
}

Academic Editor: Pierre Koch

Received: 29 March 2017; Accepted: 29 May 2017; Published: 31 May 2017

\begin{abstract}
Signaling pathways of VEGFs and PDGFs are crucial in tumor angiogenesis, which is essential in solid tumor progression and metastasis. This study reports our strategy for designing and synthesizing a series of novel 2-pyrrolidone-fused (2-oxoindolin-3-ylidene)methylpyrrole derivatives as potential multi-target tyrosine kinase receptor inhibitors. The target compounds were obtained by condensation of 5-substituted oxindoles with $\mathrm{N}$-substituted 2-pyrrolidone aldehyde 7 in satisfactory yields. Of these, $\mathbf{1 1}$ and $\mathbf{1 2}$ had the highest potency and, compared to sunitinib, showed: (1) significant increase in anti-proliferation of various cancer cells with a favorable selective index (SI); (2) higher inhibitory potency against both VEGFR-2 and PDGFR $\beta$. The molecular modeling results showed that, in terms of VEGFR-2 binding, the synthesized products had a similar binding mode to sunitinib but with tighter interaction.
\end{abstract}

Keywords: multi-target kinase inhibitor; VEGFR-2 inhibitor; PDGFR $\beta$ inhibitor angiogenesis; (2-oxoindolin-3-ylidene)methylpyrrole

\section{Introduction}

Angiogenesis, a process of new blood vessel formation from pre-existing vessels, is pivotal in both physiological, such as wound healing, reproduction and embryonic development, and pathophysiological, such as rheumatoid arthritis, atherosclerosis and cancer, conditions [1]. Of the six distinguishing characteristics of cancer, tumor angiogenesis is considered among the most important hallmarks of cancer because it exacerbates malignant cancer growth and metastatic dissemination [2]. To excrete tumor metabolic waste and supply oxygen and nutrients for tumor growth, new blood vessels are essentially formed if the tumor size is beyond $2 \mathrm{~mm}^{3}$. To avoid apoptosis, necrosis and/or provide paths for metastasis to survive, tumor cells secrete several pro-angiogenesis factors inducing new blood vessel formation near tumor tissues [3]. These factors include vascular endothelial growth factors (VEGF), platelet-derived growth factors (PDGF), and epidermal growth factors (EGF) [3]. Restricting new blood vessel formation around tumor tissues may also reduce tumor size and/or avoid metastasis and thus bring beneficial effects of targeted therapy.

Many factors, including VEGFs, PDGFs and their receptor tyrosine kinases (RTKs), VEGF receptors 1-3 (VEGFR1-3), and PDGF receptor- $\alpha$ and $-\beta$ (PDGFR- $\alpha / \beta)$, participate in tumor-induced angiogenesis signaling pathways in the tumor microenviroment [4]. Among them, VEGFR-1 and -2, key receptors in tumor-induced angiogenic signal transduction, promote endothelial cell proliferation, 
migration, and survival [3-5]. Moreover, PDGFs and PDGFRs support tumor-induced angiogenesis by stimulating proliferation of both fibroblasts and vascular smooth muscle cells, both of which stabilize newly formed blood vessels [5]. Thus, targeting both VEGFs and PDGFs signaling is considered a promising approach to developing anti-angiogenesis drugs.

In 1971, Folkman proposed that anti-angiogenesis might be an effective strategy for cancer treatment [3]. Sice then, various potent small-molecule ATP-competitive VEGFR inhibitors, such as dasatinib, sorafenib, semaxanib (SU5416), orantinib (SU6668), and sunitinib (Figure 1), have been developed and some of them have been approved [6-9]. Semaxanib was the first of these to be clinically tested as a receptor tyrosine kinase (RTK) inhibitor for VEGFRs [9]. The lipophilic (2-oxoindolin-3-ylidene)methylpyrrole moiety in semaxanib was then identified as a prerequisite for the inhibitory activity against ATP-competitive RTKs. Further structural modification of semaxanib successfully introduced a substituted pyrrole indolinone derivative sunitinib as a very potent and orally effective anti-angiogenesis agent inhibiting cellular signaling by targeting multiple RTKs, including VEGFRs, PDGFRs, aurora kinases (A, B and C), RET, Flt-3, CSF-1R, and c-Kit [10-13]. The USFDA approved the use of sunitinib for treating advanced renal cell carcinoma (RCC), gastrointestinal stromal tumors (GISTs), and imatinib-intolerant and -refractory GISTs. Sunitinib was also the first cancer drug simultaneously approved for different indications because of its inhibiting effects in signal pathways that have important roles in both tumor angiogenesis and tumor cell proliferation [14]. Afterwards, multitudinous (2-oxoindolin-3-ylidene)methylpyrrole derivatives have been designed and synthesized as potent small-molecule RTK inhibitors [15-19].

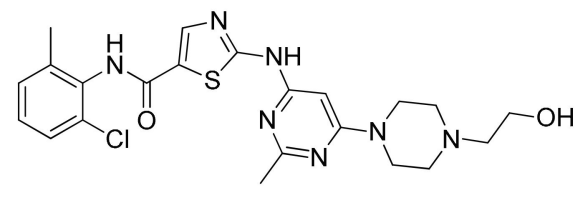

dasatinib

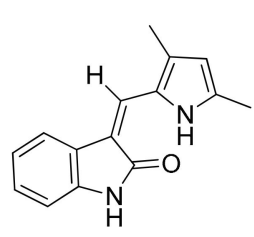

semaxanib

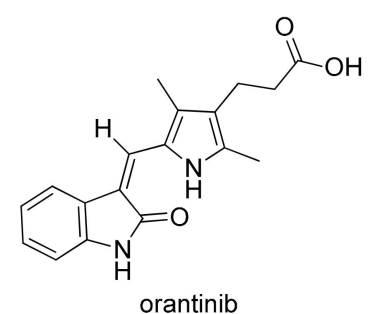

orantinib

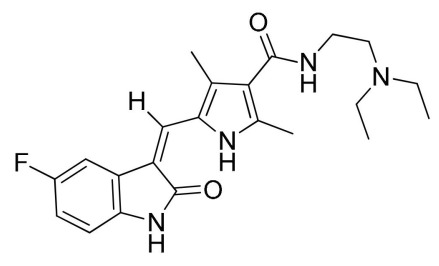

sunitinib

Figure 1. The structures of some multi-targeted kinase inhibitors. Some inhibitors, such as semaxanib, orantinib, and sunitinib, share a common structure of (2-oxindolin-3-ylidene)methylpyrrole nucleus.

Molecular modeling has indicated that the oxindole moiety of sunitinib, crucial for binding to the ATP binding site of RTKs, occupies the adenine pocket and supplies two hydrogen bonds for binding VEGFR2 (Glu917 and Cys919) [20,21]. Additionally, both the pyrrole functionality and the C(5)-F element of (2-oxoindolin-3-ylidene)methylpyrrole in sunitinib structure enhance affinity by inducing further hydrophobic interactions [20]. In contrast, the water-soluble diethylaminoethyl tail of sunitinib lies on the protein surface $[19,22,23]$. The RTK inhibitory activity and selectivity of (2-oxoindolin-3-ylidene)methylpyrrole derivatives revealed a strong relationships with structural modifications. Jun changed the methylpyrrole part of sunitinib into a bicyclic $N$-substituted pyrrolo-fused six-, seven-, and eight-membered heterocycles to obtain a series of more rigid analogs. They discovered certain products as potent inhibitors of VEGFR-2, PDGFR $\beta$ and c-kit both enzymatically and cellularly [19]. This study reports the design, synthesis, and structure-activity 
relationships (SARs) of a series of novel (2-oxoindolin-3-ylidene)methylpyrrole derivatives, bearing at $\mathrm{C}(5)$ of oxindole various halogens, fused with an $\mathrm{N}$-substituted 2-pyrrolidone which might result in a smaller, flatter, and more rigid conformation (Figure 2), and thus restrict the ability of the hydrophilic diethylaminoethyl tail to rotate in the hope of facilitating the binding affinity. The target molecules were prepared by condensation of 5-substituted oxindoles with $N$-substituted 2-pyrrolidone aldehyde 7 . Several of the resulting compounds proved to be potent small-molecule kinase inhibitors. Among them, $\mathbf{1 1}$ and $\mathbf{1 2}$ consistently displayed the most potent activities and favorable selective indexes (SI) and thus were chosen as the candidates for further preclinical development.

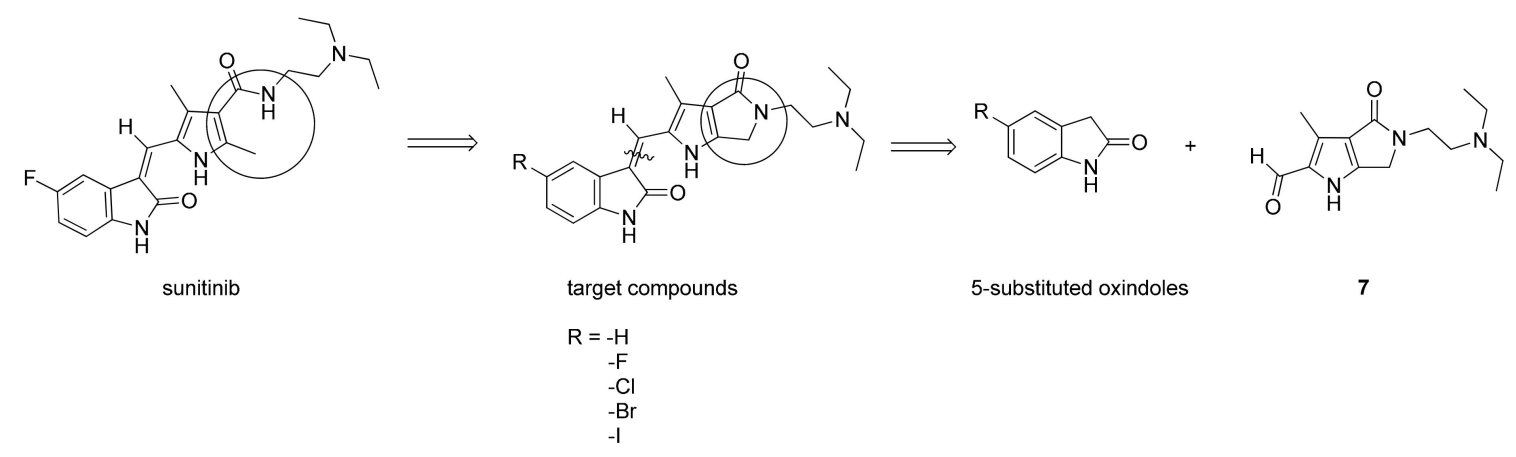

Figure 2. Drug design, and retrosynthetic approach of the target compounds.

\section{Results and Discussion}

\subsection{Chemistry}

Scheme 1 outlines the synthetic sequence that our laboratory used to prepare targets 8-12. The starting material 2-tert-butyl 4-ethyl 3,5-dimethyl-1H-pyrrole-2,4-dicarboxylate (1) was synthesized via the Paal-Knorr pyrrole synthesis [24]. Selective oxidation on $\alpha$-methyl of $\mathbf{1}$ with ceric ammonium nitrate (CAN) at room temperature for $1 \mathrm{~h}$ quantitatively formed 2 , which bore an $\alpha$-formyl functionality at the pyrrole ring. Compound 2 was then coupled with $N, N$-diethylethylenediamine, and then, without isolation, reduced directly with activated sodium borohydride/p-toluenesulfonic acid in ethanol to obtain $\mathbf{3}$ in a satisfactory yield [25]. Ester $\mathbf{3}$ was hydrolyzed in methanol into carboxylic acid 4 . Compound 4 was transformed into 5 by lactamization promoted by $1,1^{\prime}$-carbonyldiimidazole (CDI). Hydrolytic decarboxylation of 5 with sulfuric acid in methanol could provide 6 . Without purification, 6 was used directly for selective formylation at C(5) to yield 7, achieved smoothly by treatment with a Vilsmeier rfeagent. Condensation of 7 with 5-substitued oxindoles in the presence of piperidine at room temperature afforded target molecules.

The key intermediate 3 was initially synthesized using methods described in the literature [25]. First, reductive amination was performed to transform the carbonyl group directly to its corresponding amine derivative 3 by treating aldehyde 2 with $\mathrm{N}, \mathrm{N}$-diethylethylenediamine followed by $p$-toluenesulfonic acid monohydrate-activated sodium borohydride under solvent-free conditions; however, compound 3 was obtained in only $43 \%$ yield, along with a string of unidentifiable impurities. In our modified experiments, ethanol was used as the solvent for reductive amination of 2 . The resulting yield substantially increased to $90 \%$. We hypothesized that the use of ethanol in this reaction vastly improved the yield of 3 because the protic polar solvent ethanol might effectively be involved in the formation of an appropriate transition state required for the subsequent reductive amination and thus greatly facilitated the reaction. The unreacted $\mathbf{2}$ and all the impurities generated were then easily removed by column chromatography. 

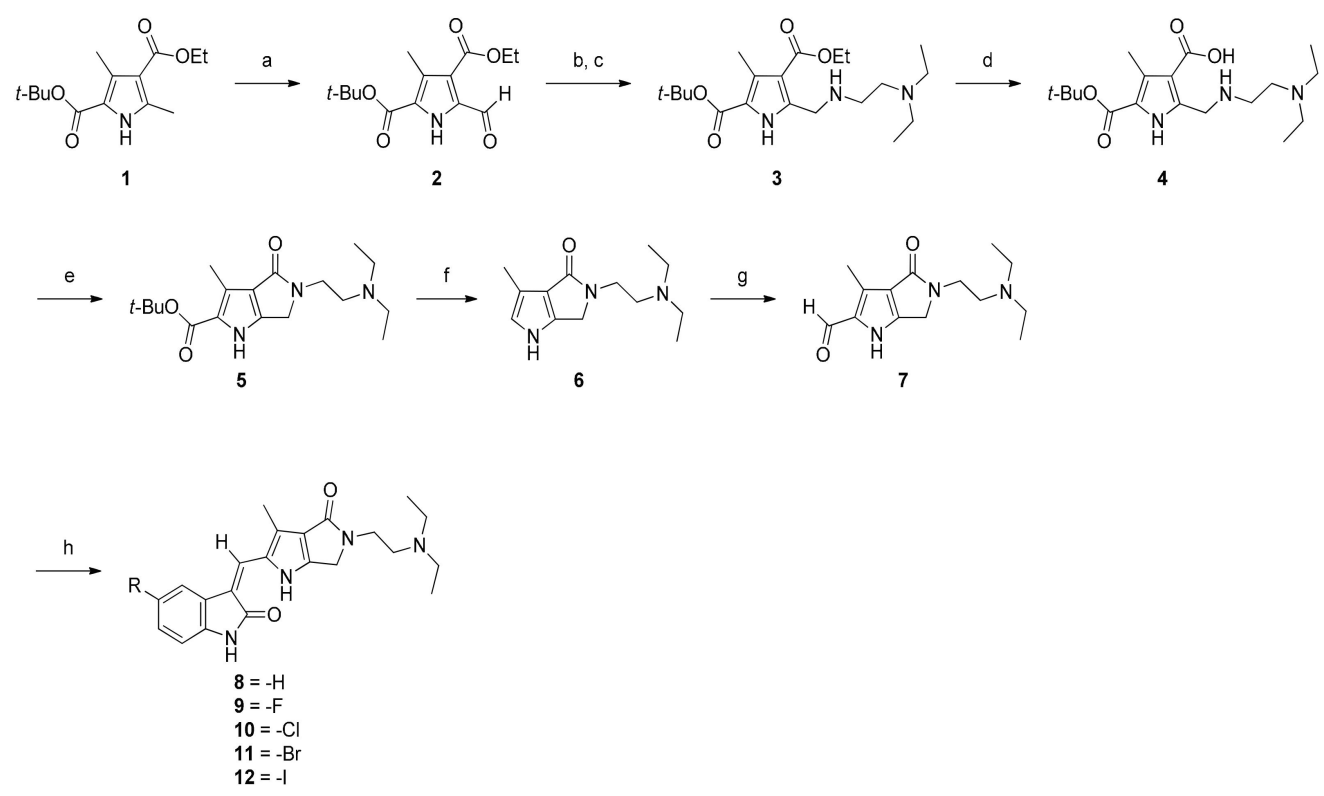

Scheme 1. Synthesis of $N$-substituted 2-pyrrolidone fused (2-oxoindolin-3-ylidene)methylpyrrole derivatives. Reagents and conditions: (a) CAN, THF, AcOH, $\mathrm{H}_{2} \mathrm{O}, 1 \mathrm{~h}, 98 \%$; (b) $N, N$-diethylethylenediamine, EtOH, r.t., 4 h; (c) $\mathrm{NaBH}_{4}$, $\mathrm{TsOH} \mathrm{H}_{2} \mathrm{O}, 6$ h, $90 \%$; (d) $1 \mathrm{~N} \mathrm{NaOH}_{(\mathrm{aq})}, \mathrm{MeOH}, 65^{\circ} \mathrm{C}, 6$ h, $96 \%$; (e) CDI, dry $\mathrm{THF}, 6 \mathrm{~h}, 56 \%$; (f) $\mathrm{H}_{2} \mathrm{SO}_{4}, \mathrm{MeOH}$, reflux, $4.5 \mathrm{~h}$; (g) Vilsmeier reagent, DCM, r.t., 5 h, 91\%; (h) piperidine, indoline-2-ones, $\mathrm{EtOH}$, r.t., 5 h, $43-56 \%$.

In the synthesis of the first bicyclic compound 5, Jun revealed that an elegant direct lactamization that formed lactams with medium size (six-, seven-, and eight-membered ring) could be used either by treating I with lithium hydroxide or with trimethylaluminium, followed by treating with $2 \mathrm{M}$ hydrochloric acid if decarboxylation products were desired, to give pyrrolo-fused-heterocycles-2-indolinones II in the yield of 27-97\% (Scheme 2) [19]. Their experimental results showed that lactamization yields correlated with the ring size of the products. The marked success of Jun in synthesizing medium-sized lactams with simultaneous decarboxylation prompted us to prepare the smaller but desired lactam 6. By applying this seemingly promising approach, our synthesis of $\mathbf{6}$ would have been achieved in a single step starting from 3 . Unfortunately, all our attempt lactamization of 3 , based on this strategy, to obtain desired 5 under various conditions failed and culminated in producing the hydrolyzed product 4 . Reactions at higher temperatures only gave trace amount of the product. Variation in solvents and use of microwave irradiation usually obtained yields approximating $10 \%$. Even the modified method using DABAL-Me $e_{3}$ or $\mathrm{AlMe}_{3} / \mathrm{DABAL}_{-\mathrm{Me}}$ or all other similar approaches under various conditions proved to be fruitless [25-29]. The likely culprit is the significant difference in the ring strain between $\mathbf{6}$ and II $(n=1,2,3)$. These experimental results clearly indicate that the Jun's method of lactamization excludes the preparation of $\mathrm{N}$-substituted 2-pyrrolidone derivatives to be used in our synthesis.

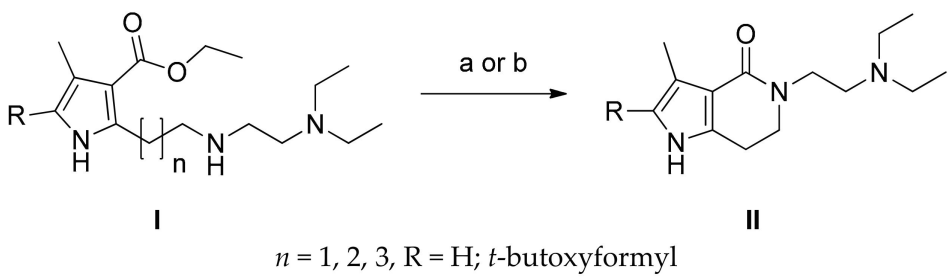

Scheme 2. Synthesis of pyrrolo-fused-heterocycles-2-indolinones II [19]. Reagents and conditions: (a) $\mathrm{LiOH} /$ ethylene glycol; (b) AlMe 3 , toluene, then $\mathrm{HCl}$. 
Our laboratory finally found a way to circumvent the predicament in a stepwise manner. First, ester 3 was hydrolyzed into carboxylic acid 4 with $1 \mathrm{~N}$ sodium hydroxide in $96 \%$ yield. Performing CDI-mediated lactamization of the resulting zwitterionic compound 4 in dry tetrahydrofuran under a nitrogen atmosphere proved effective for synthesizing the desired fused pyrrole 5 in $56 \%$ yield. Compound 5 was then subjected to hydrolytic decarboxylation with sulfuric acid under a reflux condition to provide $\mathbf{6}$. Without isolation and purification, crude $\mathbf{6}$ was smoothly formylated at C(2) by treatment with a Vilsmeier reagent in dichloromethane to furnish 7 in $91 \%$ yield. Condensation of 7 with 5-substitued oxindoles afforded target molecules 8-12 in 43-56\% yields.

All target compounds were isolated as free bases. In most cases, crystallization or column chromatography was required for purification. The structures of most synthetic intermediates and products were established by spectroscopy and high-resolution mass spectrometry.

\subsection{Anti-Proliferation Activity and Acute Cytotoxicity}

Table 1 shows the in vitro anti-proliferation activity of the synthetic products 8-12 against human colon cancer line HCT116, human non-small cell lung cancer cells NCI-H460, and human renal cell carcinoma 786-O. For comparison, sunitinib was employed as a positive control. The preliminary results showed that all synthetized compounds had significant inhibiting effects on HCT-116 cancer cell proliferation, but for 8 which bears $\mathrm{C}(5)-\mathrm{H}$. While the $\mathrm{IC}_{50}$ values of $\mathbf{9}(\mathrm{C}(5)-\mathrm{F})$ and $\mathbf{1 0}(\mathrm{C}(5)-\mathrm{Cl})$ were approximately equal to that of sunitinib $\left(\mathrm{IC}_{50} 3.42 \pm 0.57 \mu \mathrm{M}\right)$, the values for $11(\mathrm{C}(5)-\mathrm{Br})$ $\left(\mathrm{IC}_{50} 1.05 \pm 0.18 \mathrm{M}\right)$ and $\mathbf{1 2}(\mathrm{C}(5)-\mathrm{I})\left(\mathrm{IC}_{50} 0.42 \pm 0.16 \mu \mathrm{M}\right)$ were much better. As to the anti-proliferation effect on the NCI-H460 cells, $\mathbf{8 - 1 0}$ showed poor inhibitory activity ( $\left.\mathrm{IC}_{50}>10 \mu \mathrm{M}\right) ; \mathbf{1 1}$ was approximately equal in potency to sunitinib ( $\mathrm{IC}_{50}=6.57$ and $6.23 \mu \mathrm{M}$, respectively). Notably, 12 revealed prominent inhibitory activity $\left(\mathrm{IC}_{50}=2.95 \mu \mathrm{M}\right)$. As to the anti-proliferation effect on the 786-O cells, both 8 and 9 were once again void of activity $\left(\mathrm{IC}_{50}>10 \mu \mathrm{M}\right)$. The potencies of compounds 10-12 (IC $\mathrm{IC}_{50}$ approximately $7 \mu \mathrm{M}$ ) were comparable to that of sunitinib.

Table 1. Cellular activities and selective indexes of 8-12 and sunitinib.

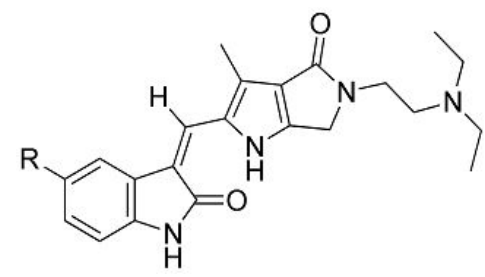

\begin{tabular}{|c|c|c|c|c|c|}
\hline \multirow{2}{*}{ Compd. } & \multirow{2}{*}{$\mathbf{R}$} & \multicolumn{4}{|c|}{$\mathrm{IC}_{50}(\mu \mathrm{M}) /$ Selective Index $(\mathrm{SI})$} \\
\hline & & HCT116 & NCI-H460 & $786-\mathrm{O}$ & Detroit 551 \\
\hline Sunitinib & - & $\begin{array}{l}3.42 \pm 0.57 \\
2.77\end{array}$ & $\begin{array}{l}6.23 \pm 0.57 \\
1.52\end{array}$ & $\begin{array}{l}6.27 \pm 0.67 \\
1.51\end{array}$ & $9.48 \pm 0.18$ \\
\hline 8 & $-\mathrm{H}$ & $\begin{array}{l}4.25 \pm 1.88 \\
>2.35\end{array}$ & $\begin{array}{l}>10 \\
\text { nd }\end{array}$ & $\begin{array}{l}>10 \\
\text { nd }\end{array}$ & $>10$ \\
\hline 9 & $-F$ & $\begin{array}{l}2.94 \pm 0.66 \\
>3.4\end{array}$ & $\begin{array}{l}>10 \\
\text { nd }\end{array}$ & $\begin{array}{l}>10 \\
\text { nd }\end{array}$ & $>10$ \\
\hline 10 & $-\mathrm{Cl}$ & $\begin{array}{l}3.09 \pm 0.70 \\
>3.23\end{array}$ & $\begin{array}{l}>10 \\
\text { nd }\end{array}$ & $\begin{array}{l}7.30 \pm 1.20 \\
>1.37\end{array}$ & $>10$ \\
\hline 11 & $-\mathrm{Br}$ & $\begin{array}{l}1.05 \pm 0.18 \\
>9.52\end{array}$ & $\begin{array}{l}6.57 \pm 1.64 \\
>1.52\end{array}$ & $\begin{array}{l}7.06 \pm 0.30 \\
>1.42\end{array}$ & $>10$ \\
\hline 12 & $-\mathrm{I}$ & $\begin{array}{l}0.42 \pm 0.16 \\
21.93\end{array}$ & $\begin{array}{l}2.95 \pm 0.83 \\
3.12\end{array}$ & $\begin{array}{l}7.76 \pm 0.29 \\
1.19\end{array}$ & $9.21 \pm 1.61$ \\
\hline
\end{tabular}

nd: not detected. 
Potential anticancer drug candidates should have greater selectivity for tumor cells compared with normal cells. Therefore, human normal fibroblast cells Detroit 551 were used for evaluation so as to indicate the selective indexes of 8-12 and sunitinib. In Table 1, our synthetic compounds generally showed much less toxicity to Detroit 551 cells than sunitinib. Even potent $\mathbf{1 2}$ had high selectivity against HCT116 and NCI-H460 cancer cell lines.

To exclude the possibility that the inhibitory responses of sunitinib and compounds 8-12 were resulted from the acute cytotoxicity of indicated compounds, this study performed a WST-8 assay to assess their effects of acute cellular toxicity on Detroit 551, HCT116, NCI-H460 and 786-O cell lines. Figure 3 shows the experimental results. The results clearly revealed that all the synthetic products 8-12, together with sunitinib, were nearly free from acute cellular toxicity on all the tested cell lines.

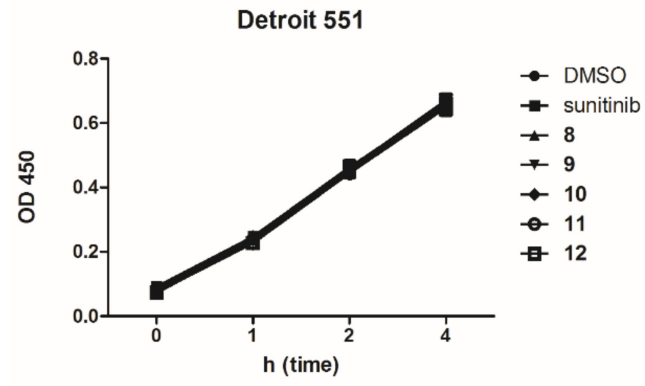

(a)

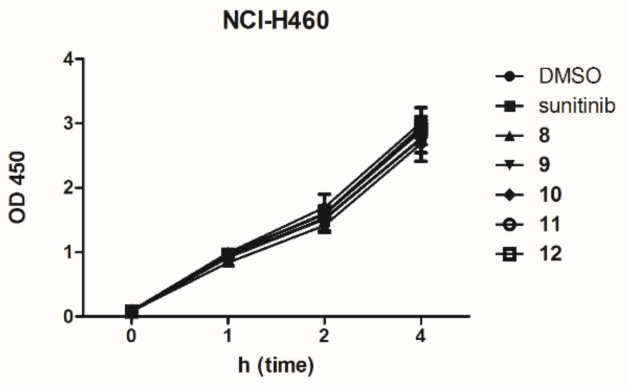

(c)

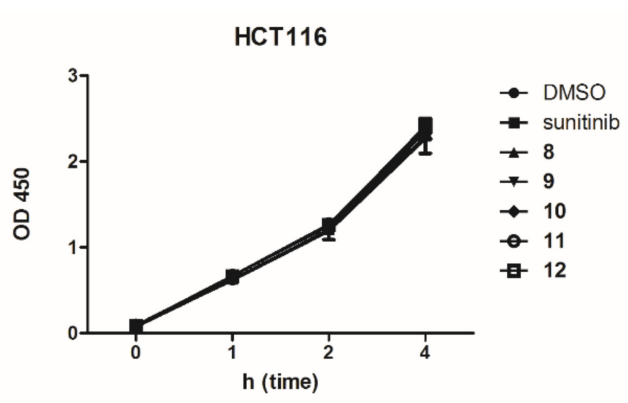

(b)

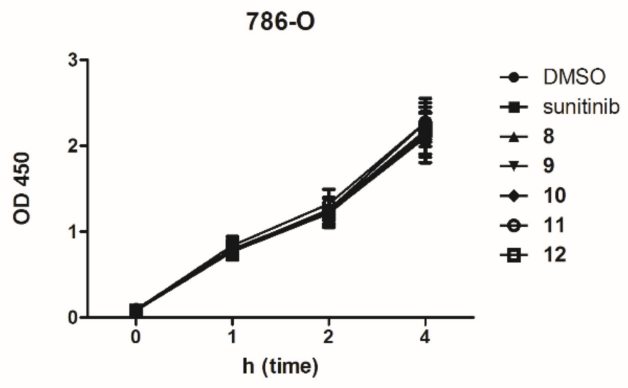

(d)

Figure 3. Acute cytotoxicity assay of (a) Detroit 551; (b) HCT116; (c) NCI-H460; (d) 786-O cells incubated with DMSO (1\%), sunitinib and 8-12 (10 $\mu \mathrm{M})$.

In the (2-oxoindolin-3-ylidene)methylpyrrole system, the $C(5)$ halogen substituent is known to have critical roles in the cytotoxicity and anti-proliferation of cancer cells $[16,18,19,30,31]$. Structural modification of sunitinib by replacing the fluorine atom on $\mathrm{C}(5)$ with an iodine led to approximately 23-fold weaker potency against HT29 cells [30]. In our 2-pyrrolidone-fused (2-oxoindolin-3-ylidene)methylpyrrole system, compound 9 (C(5)-F) had approximately equal or slightly better potency in the anti-proliferation activity against HCT116 to that of sunitinib ( $\mathrm{IC}_{50} 2.94 \mu \mathrm{M}$ vs. $\left.3.42 \mu \mathrm{M}\right)$. The corresponding 10 (C(5)-Cl), 11, (C(5)-Br) and $12(\mathrm{C}(5)-\mathrm{I})$ showed a similar trend. For example, compound 12 was strikingly potent, with approximately 8-fold stronger than sunitinib and 10-fold stronger than $8(\mathrm{C}(5)-\mathrm{H})$.

Apoptosis of human colon cancer cells, including HCT116 and HT29 cells, can be induced by VEGFR-2 inhibitors, such as regorafenib, crizotinib, sorafenib, and sunitinib, via p53 upregulated modulator of apoptosis (PUMA) [32-35]. Recently, Zhang demonstrated that PUMA could be transcriptionally activated via the NF-кB pathway after aurora kinase inhibition in HCT116 cells [36]. Sunitinib has well recognized inhibitory activity against aurora kinase, and the six-membered cycloalkanone fused (2-oxoindolin-3-ylidene)methylpyrroles exhibit further improvement in the inhibition of aurora kinase [18]. We hypothesized that our synthetic derivatives might have a profound effect on the binding affinity of aurora kinase. Therefore, an aurora A kinase inhibition percentage at 
$1.0 \mu \mathrm{M}$ of sunitinib and the synthetic compounds were thus assessed to validate our hypothesis. Table 1 shows the experimental results, which indicated that all our newly synthetic products showed excellent but without noticeably differentiating inhibitory activity against aurora A (92.1-95.9\%), comparing to sunitinib (50.7\%). Thus, these results suggested that, in binding to and inhibition of aurora A, compared to the conformation of the bicycle pyrrole scaffold, the $C(5)$ substitution effect might play a less significant role.

Inhibition of aurora kinase leads to a polyploidy cell cycle profile [18,37]. The cell cycle profile of HCT116 cells incubated with compounds $\mathbf{8}$ and $\mathbf{1 1}$ for 24 h exhibited an increase phase of polyploid (Figure 4c,f). Surprisingly, the cell cycle profile of HCT116 cells incubated with sunitinib, 9, 10, and 12 for 24 h caused G0/G1 cell cycle arrest (Figure 4b,d,e,g). The best explanation is that compounds 8 and 11 inhibited HCT116 cells proliferation via significant aurora kinase inhibition while sunitinib, 9, 11 and 12 might be otherwise involved in different mechanisms.

In summary, the experiments in this study suggest that the structural skeleton constructed by fusion of (2-oxoindolin-3-ylidene)methylpyrrole with $\mathrm{N}$-substituted 2-pyrrolidone and introduction of a proper halogen at $\mathrm{C}(5)$ of oxindole has a strong influence on both anti-proliferation activity and selectivity. The $\mathrm{C}(5)$-halogen substituents of the title compounds seemed to be advantageous in general and had marked effect: the bulkier halogen the substituent is, the stronger anti-proliferation activity it has.

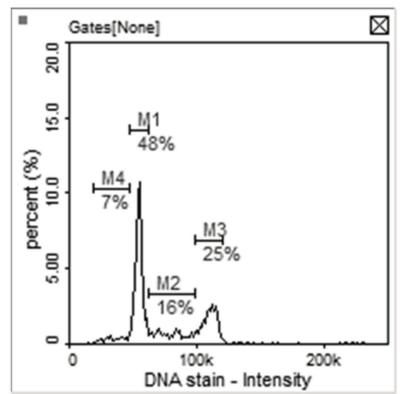

(a)

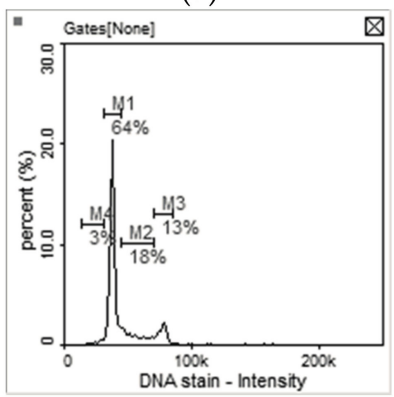

(d)

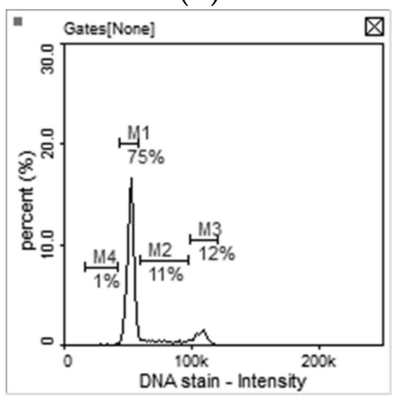

(g)

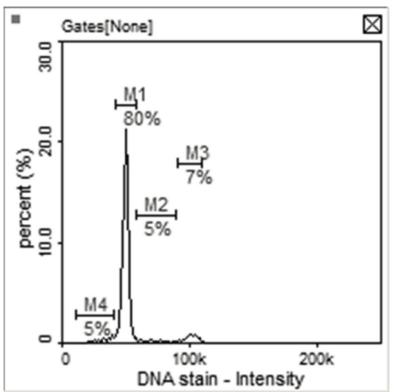

(b)

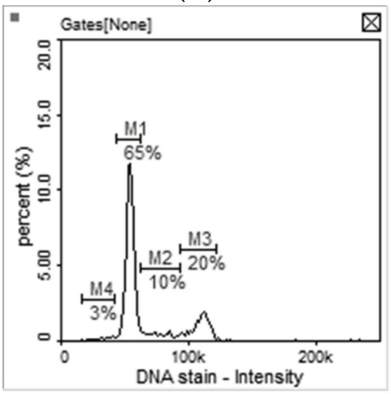

(e)

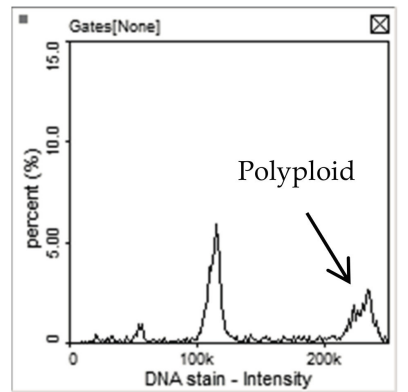

(c)

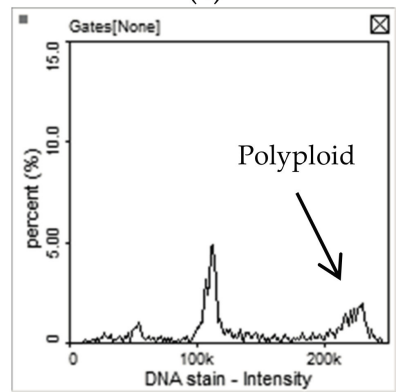

(f)

Figure 4. Cell cycle profiles of HCT-116 cells treated with (a) 1\% DMSO (control); (b) $5.0 \mu \mathrm{M}$ of sunitinib; (c) $5.0 \mu \mathrm{M}$ of 8; (d) $5.0 \mu \mathrm{M}$ of 9; (e) $5.0 \mu \mathrm{M}$ of 10; (f) $1.0 \mu \mathrm{M}$ of 11; (g) $1.0 \mu \mathrm{M}$ of 12 for $24 \mathrm{~h}$. M1: G0/G1phase, M2: S phase, M3: G2/M phase. 


\subsection{Kinase Inhibitory Assays}

Table 2 shows the results of kinase inhibition assays for compounds 8-12, compared to sunitinib. The $\mathrm{IC}_{50}$ values for 8, 10, 11, and, 12 against VEGFR-2 were 4- to 6-fold higher, and their $\mathrm{IC}_{50}$ values against PDGFR $\beta$ were approximately 2- to 4-fold higher and $\mathbf{1 1}$ was the most potent. Comparing with sunitinib, The results once again displayed the similar trend that different $C(5)$ substitutions had significant influence on the biochemical activities against VEGFR-2 and PDGFR $\beta$.

Unexpectedly, comparisons with $\mathrm{C}(5)-\mathrm{H}(\mathbf{8})$ and other $\mathrm{C}(5)$-halogen analogs (10, 11, and 12) showed that compound $9(\mathrm{C}(5)-\mathrm{F})$ had much lower inhibitory activity against both VEGFR-2 and PDGFR $\beta$ and, comparing to sunitinib, only little increase in inhibitory activity against VEGFR-2 but decrease against PDGFR $\beta$. These results markedly differed from the results reported in experiments using 2-piperidinone fused (2-oxoindolin-3-ylidene)methylpyrrole derivatives [19]. The influence of the difference in ATP binding sites between VEGFR-2 and PDGFR $\beta$ is apparent and complex yet nevertheless not very clear. A possible explanation for the increased inhibitory activity of VEGFR-2 is a better accommodation to (2-oxoindolin-3-ylidene)methylpyrroles with C(5)-halides, except for $\mathrm{C}(5)-\mathrm{F}$.

Table 2. Enzymatic activities and LibDock score of 8-12 and sunitinib.

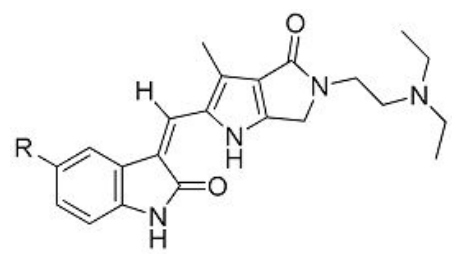

\begin{tabular}{|c|c|c|c|c|c|c|c|}
\hline Compd. & $\mathbf{R}$ & \multicolumn{2}{|c|}{$\%$ Inhibition at $50 \mathrm{nM}$} & \multicolumn{2}{|c|}{$\mathrm{IC}_{50}(\mathrm{nM})$} & $\begin{array}{c}\% \text { Inhibition of } \\
\text { Aurora A at } 1.0 \mu \mathrm{M}\end{array}$ & $\begin{array}{l}\text { LibDock Score of } \\
\text { VEGFR-2 Binding }\end{array}$ \\
\hline Sunitinib & - & 29 & 44 & 140.0 & 61.4 & 50.7 & 110.303 \\
\hline 9 & $-F$ & 35 & 36 & 110.7 & 97.5 & 93.1 & 137.901 \\
\hline 10 & $-\mathrm{Cl}$ & 58 & 64 & 35.0 & 24.9 & 93.7 & 130.921 \\
\hline 11 & $-\mathrm{Br}$ & 64 & 68 & 24.7 & 16.1 & 93.1 & 129.433 \\
\hline
\end{tabular}

\subsection{In Vitro Tube Formation Assay}

The in vitro inhibitory activity against tube formation of compounds 8-12 was tested with an angiogenesis kit (Kurabo). Figure 5 shows that they markedly inhibited the VEGF-induced tube formation at $0.50 \mu \mathrm{M}, 0.25 \mu \mathrm{M}$, and $0.10 \mu \mathrm{M}$. Enhancement of the inhibitory activity against tube formation with $\mathrm{C}(5)$-halogen substitutions on oxindole followed the order $\mathrm{Br}>\mathrm{Cl}>\mathrm{I}>\mathrm{F}$ (Table 3). Compound $9(\mathrm{C}(5)-\mathrm{F})$ was slightly more potent than sunitinib $(p<0.05)$ and slightly less potent than 8, C(5) free from halogen substitution; Compound $11(\mathrm{C}(5)-\mathrm{Br})$ proved to be the most potent with $\mathrm{IC}_{50}$ approximately 2-fold stronger than sunitinib ( $\mathrm{IC}_{50} 179 \pm 29 \mathrm{nM}$ vs., $\left.387 \pm 16 \mathrm{nM}\right)$. The results were consistent with those for VEGFR-2 kinase inhibitory assays, which suggest that our synthetic compounds inhibit tube formation via inhibiting VEGFR-2 pathway. Therefore, we conclude that compound $\mathbf{1 1}$ is a good example of how sunitinib was significantly improved both in inhibiting biochemical activity (VEGFR-2 and PDGFR $\beta$ ) and in in vitro tube formation via our drug design. 


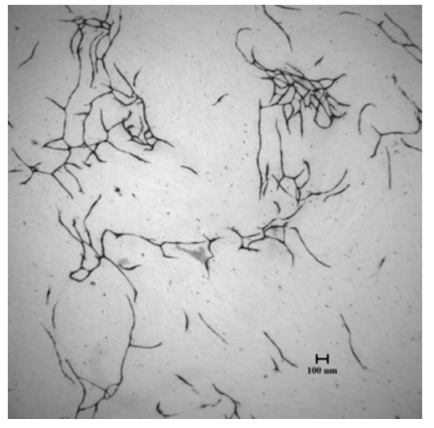

(a)

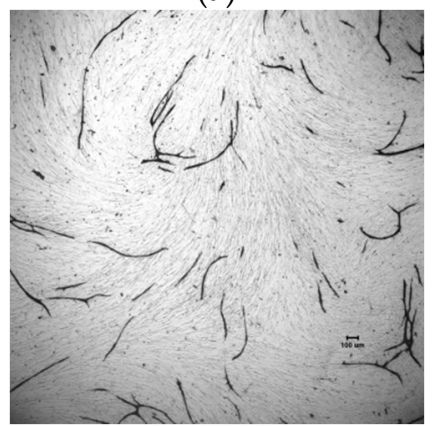

(d)

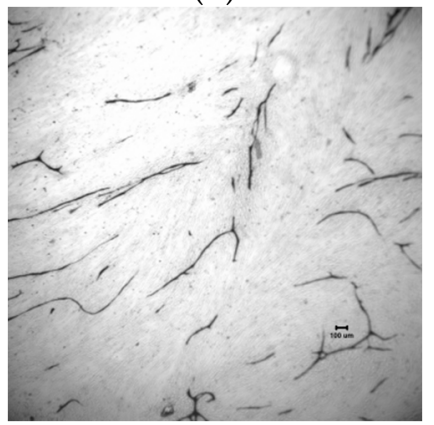

(g)

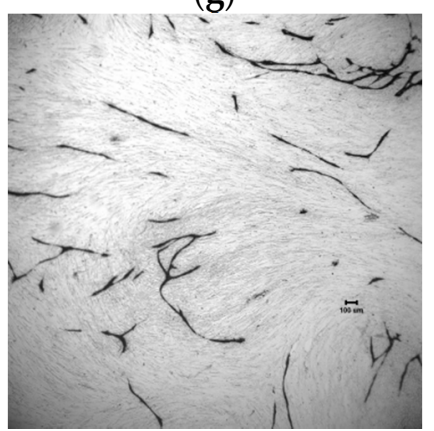

(j)

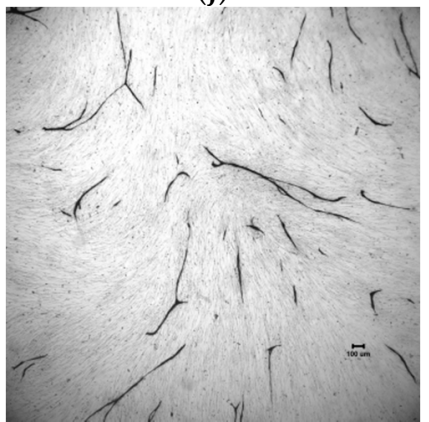

(m)

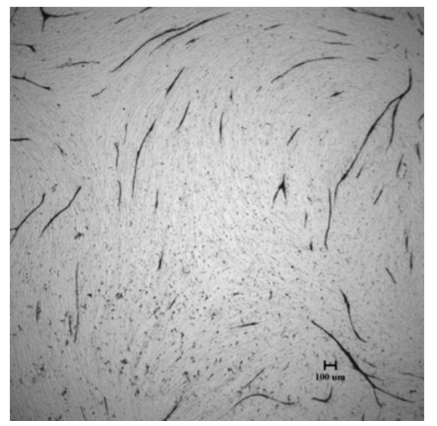

(b)

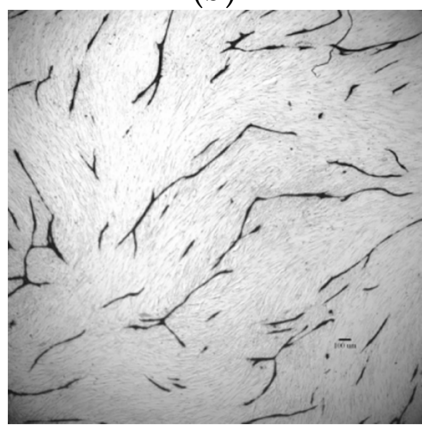

(e)

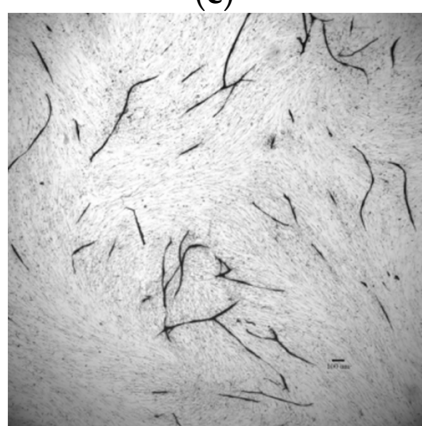

(h)

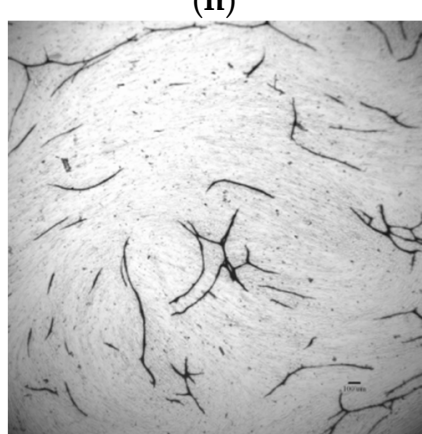

(k)

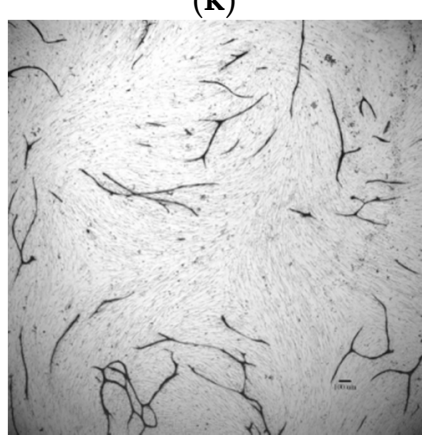

(n)

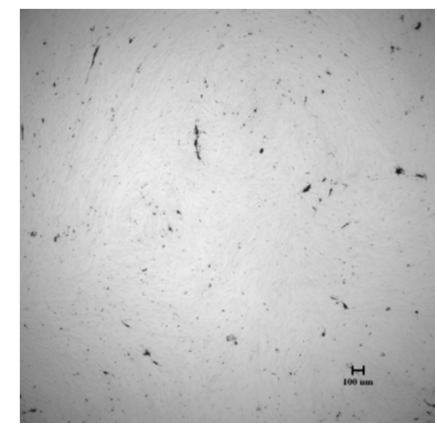

(c)

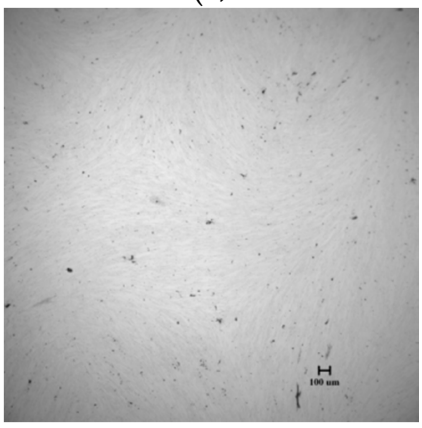

(f)

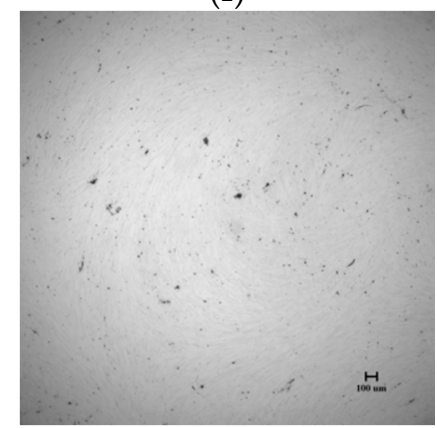

(i)

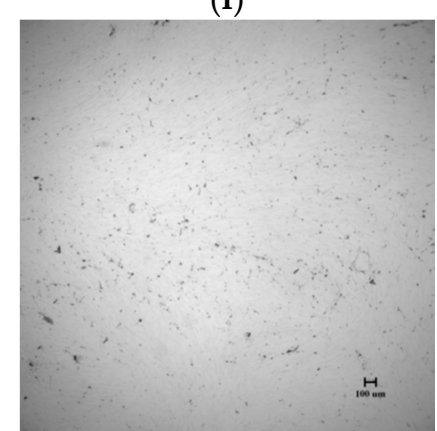

(1)

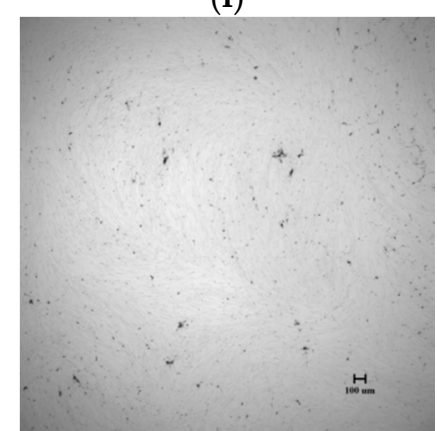

(o)

Figure 5. Cont. 


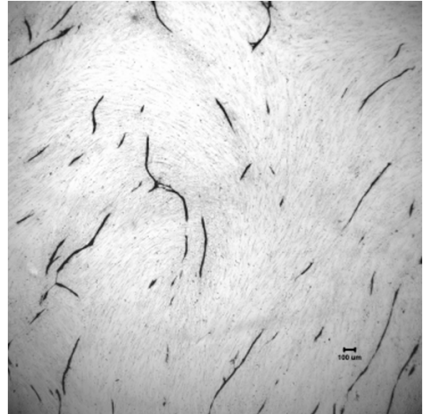

$(\mathbf{p})$

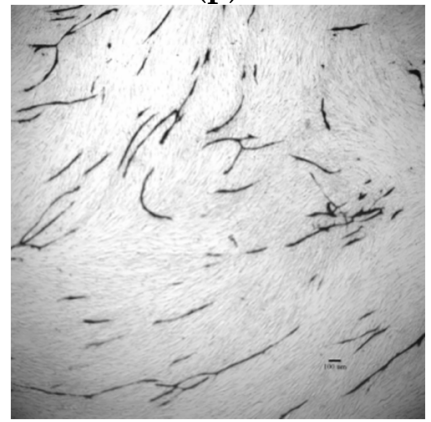

(s)

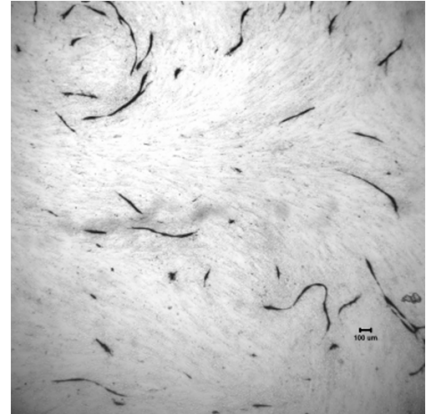

(q)

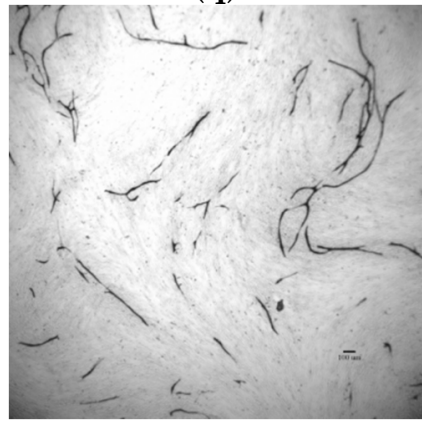

(t)

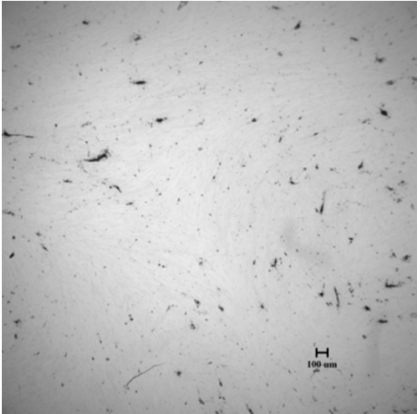

$(\mathbf{r})$

Figure 5. Compounds 8-12 inhibited tube formation induced by VEGF. Reprehensive photographs of tube formation (a) solvent control; (b) VEGFR $10 \mathrm{ng} / \mathrm{mL}$ and $70 \mu \mathrm{M}$ of suramin; (c) VEGF $10 \mathrm{ng} / \mathrm{mL}$ and $0.50 \mu \mathrm{M}$ of sunitinib; (d) VEGF $10 \mathrm{ng} / \mathrm{mL}$ and $0.25 \mu \mathrm{M}$ of sunitinib; (e) VEGF $10 \mathrm{ng} / \mathrm{mL}$ and $0.10 \mu \mathrm{M}$ of sunitinib; (f) VEGF $10 \mathrm{ng} / \mathrm{mL}$ and $0.50 \mu \mathrm{M}$ of 8; (g) VEGF $10 \mathrm{ng} / \mathrm{mL}$ and $0.25 \mu \mathrm{M}$ of 8; (h) VEGF $10 \mathrm{ng} / \mathrm{mL}$ and $0.10 \mu \mathrm{M}$ of 8; (i) VEGF $10 \mathrm{ng} / \mathrm{mL}$ and $0.50 \mu \mathrm{M}$ of $\mathbf{9}$; (j) VEGF $10 \mathrm{ng} / \mathrm{mL}$ and $0.25 \mu \mathrm{M}$ of 9; (k) VEGF $10 \mathrm{ng} / \mathrm{mL}$ and $0.10 \mu \mathrm{M}$ of 9; (1) VEGF $10 \mathrm{ng} / \mathrm{mL}$ and $0.50 \mu \mathrm{M}$ of 10; (m) VEGF $10 \mathrm{ng} / \mathrm{mL}$ and $0.25 \mu \mathrm{M}$ of 10; (n) VEGF $10 \mathrm{ng} / \mathrm{mL}$ and $0.10 \mu \mathrm{M}$ of 10; (o) VEGF $10 \mathrm{ng} / \mathrm{mL}$ and $0.50 \mu \mathrm{M}$ of 11; (p) VEGF $10 \mathrm{ng} / \mathrm{mL}$ and $0.25 \mu \mathrm{M}$ of 11; (q) VEGF $10 \mathrm{ng} / \mathrm{mL}$ and $0.10 \mu \mathrm{M}$ of 11; (r) VEGF $10 \mathrm{ng} / \mathrm{mL}$ and $0.50 \mu \mathrm{M}$ of 12; (s) VEGF $10 \mathrm{ng} / \mathrm{mL}$ and $0.25 \mu \mathrm{M}$ of 12; (t)VEGF $10 \mathrm{ng} / \mathrm{mL}$ and $0.10 \mu \mathrm{M}$ of 12 . Scale bar $=100 \mu \mathrm{m}$.

Table 3. $\mathrm{IC}_{50}$ of in vitro VEGF-induced tube formation by $\mathbf{8 - 1 2}$ and sunitinib.<smiles>[R]c1ccc2c(c1)/C(=C/c1[nH]c3c(c1C)C(=O)N(CCN(CC)CC)C3)C(=O)N2</smiles>

\begin{tabular}{ccc}
\hline Compd. & $\mathbf{R}$ & IC $_{\mathbf{5 0}}$ of Tube Area (nM) \\
\hline Sunitinib & - & $387 \pm 16$ \\
$\mathbf{8}$ & $-\mathrm{H}$ & $310 \pm 15$ \\
$\mathbf{9}$ & $-\mathrm{F}$ & $367 \pm 16$ \\
$\mathbf{1 0}$ & $-\mathrm{Cl}$ & $299 \pm 70$ \\
$\mathbf{1 1}$ & $-\mathrm{Br}$ & $179 \pm 29$ \\
$\mathbf{1 2}$ & $-\mathrm{I}$ & $313 \pm 37$ \\
\hline
\end{tabular}

\subsection{Molecular Modeling}

For a clear understanding of the interaction between the title compounds 8-12 together with sunitinib and the ATP-binding site of VEGFR-2 at the molecular level, a molecular modeling was constructed. Figure 6 shows how the test ligands were docked into the ATP-binding site of VEGFR-2 
(PDB ID: 4AGD) using Discovery studio LibDock [38]. LibDock is a method that places the generated ligand conformations into the protein active site based on polar and apolar interaction sites (hotspot), and the LibDock score was scored by default settings including Ligscore, piecewise linear potential (PLP), Jain, potential of mean force (PMF) and PMF04. The results showed the predicted binding mode of all our synthetic compounds as well as sunitinib. All our synthetic products and sunitinib formed two hydrogen bonds (important for the binding of (2-oxoindolin-3-ylidene)methylpyrrole derivatives and ATP-binding site) to VEGFR-2, with Glu917 and Cys919, respectively (Figure 6a-f). The pyrrole $\mathrm{NH}$ of $\mathbf{8 - 1 2}$ formed a hydrogen bond with $\mathrm{C}=\mathrm{O}$ of Cys919 in VEGFR-2. A hydrophobic interaction also occurred between the pyrrole moieties of 8-12 and the phenyl group of Phe918 in VEGFR-2 (Figure 6b-f). Furthermore, the diethylamine tails in 8-12 and sunitinib were exposed to the solvent without significant interaction with VEGFR-2. The interaction with VEGFR-2, compounds 8-12, as a whole, showed a similar binding mode to sunitinib but with higher LibDock score (Table 2). Although the LibDock score of 8-12 did not show consistent order with the results of 8-12 against VEGFR-2, the LibDock score of 8-12 were much higher than that of sunitinib (Table 2). However, the interaction was tighter, which might explain why most of our synthetic products exhibited potent activities in the biochemical assay.

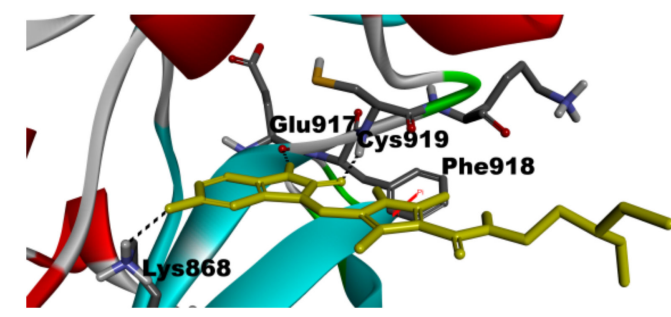

(a)

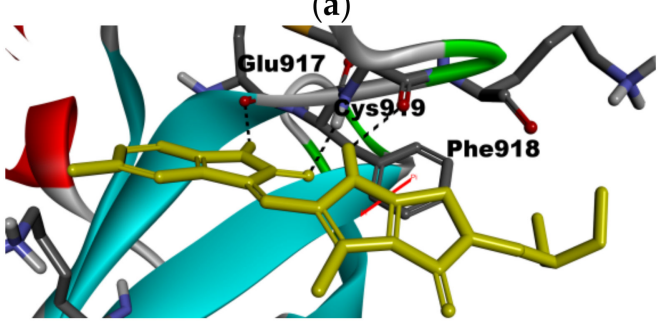

(c)

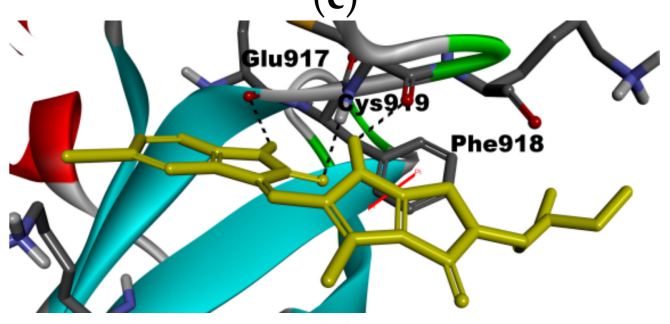

(e)

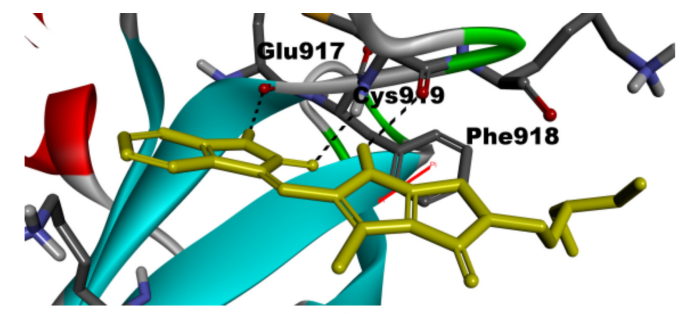

(b)

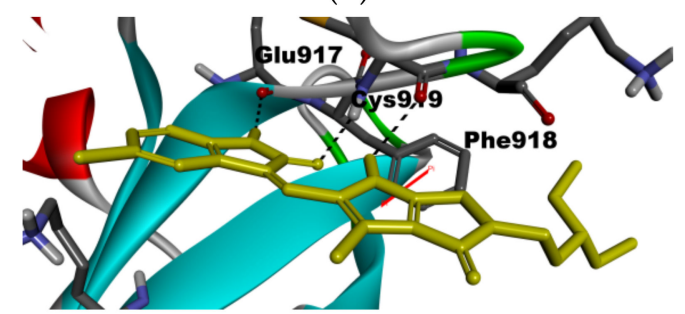

(d)

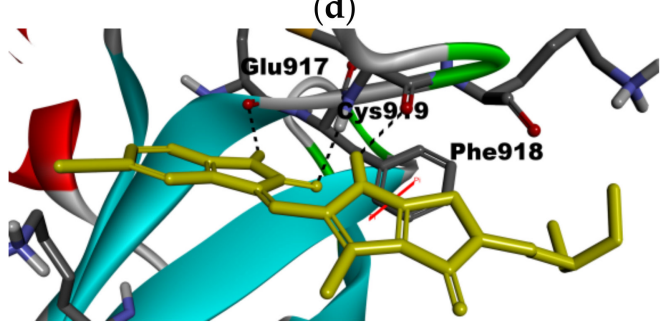

(f)

Figure 6. Docked binding modes of 8-12 in ATP binding site of VEGFR-2 (PDB ID: 4AGD) and the crystal structure of VEGFR-2 in complex with sunitinib. (a) sunitinib (from PDB ID: 4AGD) in VEGFR-2; (b) 8 in VEGFR-2; (c) 9 in VEGFR-2; (d) 10 in VEGFR-2; (e) 11 in VEGFR-2; (f) 12 in VEGFR-2. Ligands are shown in yellow sticks; hydrogen bonds are shown as dashed black lines; pi-pi interaction is shown in red line.

\section{Materials and Methods}

\subsection{Chemistry}

All the chemicals were purchased from Aldrich-Sigma Chemical Company (St. Louis, MO, USA), and Alfa-Aesar Chemical Company (Lancashire, Heysham, England) and used without further 
purification. All reactions were routinely monitored by TLC on Merck F254 silica gel plates. Silica gel (70-230 mesh, Silicacycle) was used for chromatography. The ${ }^{1} \mathrm{H}$ - and ${ }^{13} \mathrm{C}-\mathrm{NMR}$ spectra were determined on an Agilent Varian-400 NMR (Agilent Technologies, Santa Clara, CA, USA) instrument in $\mathrm{CDCl}_{3}$, methanol- $d_{4}$ or acetic acid- $d_{6}$ unless otherwise noted. Chemical shifts $(\delta)$ were expressed as parts per million (ppm) downfield from tetramethylsilane (TMS) as the internal standard ( $\sigma 0.00)$, and coupling constants $(J)$ were given in hertz $(\mathrm{Hz})$. High-resolution mass spectra (HRMS) using a Bruker Impact HD (ESI) were performed in the Instrument Center of the Ministry of Science and Technology at the National Chiao-Tung University, Taiwan. The reagents 5-chlorooxindole, 5-bromooxindole, and 5-iodiooxindole, used for the synthesis of the target products 10,11, and 12, respectively, were prepared by the modified methods [39]. Dry tetrahydrofuran was freshly distilled from lithium aluminum hydride (LAH) before use. All the other solvents were obtained from commercial sources and purified before use if necessary. Images were acquired with a Leica DM1000 microscope (Leica Microsystems, Wetzlar, Hessen, Germany). UV-VIS spectra were recorded on a Thermo Multiskan Go Microplate spectrophotometer (Thermo Fisher Scientific, Waltham, MA, USA). IR spectra were registered on a Thermo Nicolet iS5 FT-IR spectrometer (Thermo Fisher Scientific, Waltham, MA, USA) with attenuated total reflection (ATR) method. The purities of the final compounds were greater than $95 \%$ as determined by analytical reverse-phase HPLC.

\subsubsection{Synthesis of $\mathbf{2}-\mathbf{7}$}

\section{5-Formyl-3-methyl-1H-pyrrole-2,4-dicarboxylic acid 2-tert-butyl ester 4-ethyl ester (2)}

3,5-Dimethyl-1H-pyrrole-2,4-dicarboxylic acid 2-tert-butyl ester 4-ethyl ester (1) (30.0 g, $0.113 \mathrm{~mol})$ was dissolved in THF $(300 \mathrm{~mL})$. To this stirred mixture was added AcOH $(360 \mathrm{~mL})$ and water $(300 \mathrm{~mL})$ sequentially, then ceric ammonium nitrate (CAN) $(246 \mathrm{~g}, 0.45 \mathrm{~mol})$ was added to the mixture in one portion. After stirring for additional $1 \mathrm{~h}$ at room temperature, the reaction mixture was poured into ice-water $(1000 \mathrm{~mL})$, and stirred for further $30 \mathrm{~min}$. The precipitate was then filtered and dried in vacuo to yield, after crystallization from EtOAc, $31.1 \mathrm{~g}$ of analytically pure $2(98 \%)$ as pale yellow crystals. Mp: $127-128{ }^{\circ} \mathrm{C}$, lit. $120-121^{\circ} \mathrm{C}$ [40]. UV $\lambda_{\max }(\mathrm{MeOH}), \mathrm{nm}(\log \varepsilon): 238$ (3.97). IR (ATR), $\mathrm{cm}^{-1}$ : 3281, 2994, 1720, 1697, 1660. ${ }^{1} \mathrm{H}-\mathrm{NMR}\left(400 \mathrm{MHz}, \mathrm{CDCl}_{3}\right) \delta$, ppm: 10.25 (s, $\left.1 \mathrm{H}, \mathrm{CHO}\right), 9.79(\mathrm{~s}, 1 \mathrm{H}, \mathrm{NH})$, $4.38\left(\mathrm{q}, 2 \mathrm{H}, J=7.2 \mathrm{~Hz},-\mathrm{COOCH}_{2} \mathrm{CH}_{3}\right), 2.57\left(\mathrm{~s}, 3 \mathrm{H}, \mathrm{Ar}-\mathrm{CH}_{3}\right), 1.59\left(\mathrm{~s}, 9 \mathrm{H},-\mathrm{COOC}\left(\mathrm{CH}_{3}\right)_{3}\right), 1.26(\mathrm{t}, 3 \mathrm{H}$, $\left.J=7.2 \mathrm{~Hz},-\mathrm{COOCH}_{2} \mathrm{CH}_{3}\right) .{ }^{13} \mathrm{C}-\mathrm{NMR}\left(100 \mathrm{MHz}, \mathrm{CDCl}_{3}\right) \delta: 182.6,163.7,159.8,132.9,130.4,125.1,120.8$, $82.9,60.8,28.3,14.3,11.3$.

\section{2-tert-Butyl-4-ethyl 5-(((2-(diethylamino)ethyl)amino)methyl)-3-methyl-1H-pyrrole-2,4-dicarboxylate (3)}

To a stirred solution of 5-formyl-3-methyl-1H-pyrrole-2,4-dicarboxylic acid 2-tert-butyl ester 4-ethyl ester (2) $(2.81 \mathrm{~g}, 10.0 \mathrm{mmol})$ in $\mathrm{EtOH}(20 \mathrm{~mL})$ was added dropwise $N, N$-diethylethylenediamine $(1.5 \mathrm{~mL})$. The resulting mixture was stirred for $4 \mathrm{~h}$ at room temperature. Sodium borohydride $(0.38 \mathrm{~g} 10.0 \mathrm{mmol})$ and toluenesulfonic acid monohydrate $(18.0 \mathrm{~g}, 10.0 \mathrm{mmol})$ were then added to the mixture, stirred for a further $6 \mathrm{~h}$, quenched with water $(150 \mathrm{~mL})$, and extracted with ethyl acetate $(30 \mathrm{~mL} \times 3)$. The combined organic layer was dried over anhydrous $\mathrm{Na}_{2} \mathrm{SO}_{4}$ and filtered. The filtrate was evaporated in vacuo to yield, after column chromatography (silica gel, 90:10:1 EtOAc-MeOH-TEA), $3.4 \mathrm{~g}(90 \%)$ of 3 as pale yellow liquid. UV $\lambda_{\max }(\mathrm{MeOH}), \mathrm{nm}(\log \varepsilon): 228$ (3.35). IR (ATR) $\mathrm{cm}^{-1}: 3293,3216,1685,1683 .{ }^{1} \mathrm{H}-\mathrm{NMR}\left(400 \mathrm{MHz}\right.$, methanol- $\left.d_{4}\right) \delta$, ppm: $4.27(\mathrm{q}, 2 \mathrm{H}, J=7.2 \mathrm{~Hz}$, $\left.-\mathrm{COOCH}_{2} \mathrm{CH}_{3}\right), 4.05\left(\mathrm{~s}, 2 \mathrm{H}, \mathrm{Ar}-\mathrm{CH}_{2} \mathrm{~N}-\right), 2.68\left(\mathrm{t}, 2 \mathrm{H}, J=6.0 \mathrm{~Hz},-\mathrm{CH}_{2} \mathrm{NCH}_{2} \mathrm{CH}_{2}-\right), 2.55-2.49(\mathrm{~m}, 9 \mathrm{H}$, $\left.\mathrm{Ar}-\mathrm{CH}_{3},-\mathrm{NCH}_{2} \mathrm{CH}_{2} \mathrm{~N}\left(\mathrm{CH}_{2} \mathrm{CH}_{3}\right)_{2}\right), 1.55\left(\mathrm{~s}, 9 \mathrm{H},-\mathrm{COOC}\left(\mathrm{CH}_{3}\right)_{3}\right), 1.34\left(\mathrm{t}, 3 \mathrm{H}, J=7.2 \mathrm{~Hz},-\mathrm{COOCH}_{2} \mathrm{CH}_{3}\right)$, $1.00\left(\mathrm{t}, 6 \mathrm{H}, J=7.2 \mathrm{~Hz},-\mathrm{N}\left(\mathrm{CH}_{2} \mathrm{CH}_{3}\right)_{2}\right) .{ }^{13} \mathrm{C}-\mathrm{NMR}\left(100 \mathrm{MHz}, \mathrm{CDCl}_{3}\right) \delta, \mathrm{ppm}: 165.5,161.0,141.3,130.2$, $119.4,112.0,80.9,59.5,52.5,47.4,47.0,46.2,28.4,14.4,11.8,11.5$. 
2-tert-Butyl 5-(((2-(diethylamino)ethyl)amino)methyl)-3-methyl-1H-pyrrole-2,4-dicarboxylic acid (4)

To a solution of $3(2.43 \mathrm{~g}, 6.40 \mathrm{mmol})$ in $\mathrm{MeOH}(20 \mathrm{~mL})$ was added dropwise $1 \mathrm{~N} \mathrm{NaOH}(20 \mathrm{~mL})$ and the resulting mixture was then heated to reflux for $4 \mathrm{~h}$. After cooling, the mixture was neutralized with $1 \mathrm{~N} \mathrm{HCl}$ and the solvent was then evaporated under reduced pressure. $\mathrm{MeOH}(20 \mathrm{~mL})$ was added to the residue and then filtered. The filtrate was evaporated in vacuo to get, after recrystallization from hot $\mathrm{MeOH}, 2.16 \mathrm{~g}$ of analytically pure 4 (96\%) as pale yellow crystals. Mp: $119-120{ }^{\circ} \mathrm{C}$. IR (ATR), $\mathrm{cm}^{-1}:$ 3208, 1568, 1475, 1471, 1137, UV $\lambda_{\max }(\mathrm{MeOH}), \mathrm{nm}(\log \varepsilon): 222$ (2.98). ${ }^{1} \mathrm{H}-\mathrm{NMR}(400 \mathrm{MHz}$, methanol- $\left.d_{4}\right) \delta$, ppm: $4.36\left(\mathrm{~s}, 2 \mathrm{H}, \mathrm{Ar}-\mathrm{CH}_{2} \mathrm{~N}-\right), 3.58\left(\mathrm{t}, 2 \mathrm{H}, J=7.0 \mathrm{~Hz},-\mathrm{CH}_{2} \mathrm{NCH}_{2} \mathrm{CH}_{2}-\right), 2.69(\mathrm{t}, 2 \mathrm{H}$, $\left.J=7.0 \mathrm{~Hz},-\mathrm{CH}_{2} \mathrm{NCH}_{2} \mathrm{CH}_{2}-\right), 2.61\left(\mathrm{q}, 4 \mathrm{H}, J=7.2 \mathrm{~Hz},-\mathrm{N}\left(\mathrm{CH}_{2} \mathrm{CH}_{3}\right)_{2}\right), 2.41\left(\mathrm{~s}, 3 \mathrm{H}, \mathrm{Ar}-\mathrm{CH}_{3}\right), 1.57(\mathrm{~s}, 9 \mathrm{H}$, $\left.-\mathrm{COOC}\left(\mathrm{CH}_{3}\right)_{3}\right), 1.04\left(\mathrm{t}, 6 \mathrm{H}, J=7.2 \mathrm{~Hz},-\mathrm{N}\left(\mathrm{CH}_{2} \mathrm{CH}_{3}\right)_{2}\right) .{ }^{13} \mathrm{C}-\mathrm{NMR}\left(100 \mathrm{MHz}\right.$, methanol- $\left.d_{4}\right) \delta$, ppm: 169.2, $162.5,146.0,126.5,123.5,121.1,82.1,52.1,48.1,47.2,41.1,28.7,11.6,10.9$.

\section{5-(2-(Diethylamino)ethyl)-3-methyl-4-oxo-1,4,5,6-tetrahydropyrrolo[3,4-b]pyrrole-2-carboxylic acid tert-butyl ester (5)}

Compound 4 (5.44 g, $16.0 \mathrm{mmol})$ and CDI (5.19 g, $32.0 \mathrm{mmol})$ were suspended in dry THF $(300 \mathrm{~mL})$ under a nitrogen atmosphere, and then heated to $65^{\circ} \mathrm{C}$ for $6 \mathrm{~h}$. The reaction mixture was then filtered. The filtrate was evaporated under reduced pressure and the residue was purified to give, after column chromatography (silica gel, 90:10:1 EtOAc-MeOH-TEA), $3.0 \mathrm{~g}$ of the bicyclic compound 5 (56\%) as pale yellow solids. Mp: $176{ }^{\circ} \mathrm{C}$. UV $\lambda_{\max }(\mathrm{MeOH}), \mathrm{nm}(\log \varepsilon): 270$ (3.18), IR (ATR), $\mathrm{cm}^{-1}:$ 3202, $1652,1682$. ${ }^{1} \mathrm{H}-\mathrm{NMR}\left(400 \mathrm{MHz}\right.$, methanol- $\left.d_{4}\right) \delta$, ppm: 4.38 (s, 2H, $\left.\mathrm{ArCH}_{2} \mathrm{~N}-\right), 3.61\left(\mathrm{t}, 2 \mathrm{H}, J=6.9 \mathrm{~Hz},-\mathrm{NCH}_{2} \mathrm{CH}_{2}-\right)$, $2.72\left(\mathrm{t}, 2 \mathrm{H}, \mathrm{J}=6.9 \mathrm{~Hz},-\mathrm{NCH}_{2} \mathrm{CH}_{2}-\right), 2.67\left(\mathrm{q}, 4 \mathrm{H}, \mathrm{J}=7.2 \mathrm{~Hz},-\mathrm{N}\left(\mathrm{CH}_{2} \mathrm{CH}_{3}\right)_{2}\right), 1.07(\mathrm{t}, 6 \mathrm{H}, J=7.2 \mathrm{~Hz}$, -N( $\left.\left.\mathrm{CH}_{2} \mathrm{CH}_{3}\right)_{2}\right) .{ }^{13} \mathrm{C}-\mathrm{NMR}\left(100 \mathrm{MHz}, \mathrm{CDCl}_{3}\right) \delta$, ppm: 166.5, 161.7, 143.2, 125.3, 122.9, 121.7, 81.4, 52.0, $47.1,46.4,40.6,28.4,11.8,10.6$.

\section{5-(2-(Diethylamino)ethyl)-3-methyl-4-oxo-1,4,5,6-tetrahydropyrrolo[3,4-b]pyrrole-2-carbaldehyde (7)}

To a solution of $5(1.34 \mathrm{~g}, 4.00 \mathrm{mmol})$ in $\mathrm{MeOH}(100 \mathrm{~mL})$ was added dropwise $15 \% \mathrm{H}_{2} \mathrm{SO}_{4}(10 \mathrm{~mL})$. The resulting mixture was then heated to reflux for $4.5 \mathrm{~h}$. After the reaction mixture was cooled, the solution was adjusted to $\mathrm{pH} 14$ with $6 \mathrm{~N} \mathrm{NaOH}$ and extracted with ethyl acetate $(30 \mathrm{~mL} \times 3)$. The organic layers were combined and then dried over anhydrous $\mathrm{Na}_{2} \mathrm{SO}_{4}$ to obtain crude compound 6 which was used for the next step without further purification. To a solution of crude 6 (1.21 g, $5.10 \mathrm{mmol})$ in dichloromethane $(15 \mathrm{~mL})$ was added Vilsmeier reagent $(0.82 \mathrm{~g}, 6.1 \mathrm{mmol})$. The reaction mixture was allowed to stir at room temperature for $5 \mathrm{~h}$ and then was adjusted to pH $14 \mathrm{by} 1 \mathrm{~N}$ $\mathrm{NaOH}$ and extracted with ethyl acetate $(10 \mathrm{~mL} \times 3)$. The organic layers were combined and dried over anhydrous $\mathrm{Na}_{2} \mathrm{SO}_{4}$ and evaporated to give, after column chromatography (silica gel, 90:10:1 EtOAc-MeOH-TEA), $1.1 \mathrm{~g}$ of 7 (91\%) as pale yellow solids. Mp: 170-171 ${ }^{\circ} \mathrm{C}$. UV $\lambda_{\max }(\mathrm{MeOH}), \mathrm{nm}$ (loge): 221 (2.92). IR (ATR), $\mathrm{cm}^{-1}: 3093,2702,1639,1562 .{ }^{1} \mathrm{H}-\mathrm{NMR}\left(400 \mathrm{MHz}, \mathrm{CDCl}_{3}\right) \delta$, ppm: 9.20 $(\mathrm{s}, 1 \mathrm{H}, \mathrm{CHO}), 4.36\left(\mathrm{~s}, 2 \mathrm{H}, \mathrm{Ar}-\mathrm{CH}_{2}-\right), 3.56\left(\mathrm{t}, 2 \mathrm{H}, J=6.4 \mathrm{~Hz},-\mathrm{CH}_{2} \mathrm{NCH}_{2} \mathrm{CH}_{2}-\right), 2.64(\mathrm{t}, 2 \mathrm{H}, J=6.4 \mathrm{~Hz}$, $\left.-\mathrm{CH}_{2} \mathrm{NCH}_{2} \mathrm{CH}_{2-}\right), 2.55\left(\mathrm{q}, 4 \mathrm{H}, J=7.2 \mathrm{~Hz},-\mathrm{N}\left(\mathrm{CH}_{2} \mathrm{CH}_{3}\right)_{2}\right), 2.47\left(\mathrm{~s}, 3 \mathrm{H}, \mathrm{Ar}-\mathrm{CH}_{3}\right), 1.00(\mathrm{t}, 6 \mathrm{H}, J=7.2 \mathrm{~Hz}$, -N $\left.\left(\mathrm{CH}_{2} \mathrm{CH}_{3}\right)_{2}\right) .{ }^{13} \mathrm{C}-\mathrm{NMR}\left(100 \mathrm{MHz}, \mathrm{CDCl}_{3}\right) \delta$, ppm: 178.4, 165.8, 148.1, 134.1, 128.5, 121.9, 51.6, 46.6, $46.3,40.4,11.3,8.9$.

\subsubsection{Synthesis of $\mathbf{8}-\mathbf{1 2}$}

General procedure for the preparation of compounds 8-12.

To each stirred solution containing compound 7 (263 mg, $1.0 \mathrm{mmol})$ in EtOH $(15 \mathrm{~mL})$ was added dropwise a solution of 5-substituted oxindole $(1.0 \mathrm{mmol})$ in $\mathrm{EtOH}(2 \mathrm{~mL})$ and then piperidine $(0.1 \mathrm{~mL})$. After stirring at room temperature for $6 \mathrm{~h}$, the precipitate formed was filtrated, washed with EtOH, and purified by column chromatography (silica gel, 90:10:1 EtOAc-MeOH-TEA).

(Z)-3-((5-(2-(Diethylamino)ethyl)-3-methyl-4-oxo-1,4,5,6-tetrahydropyrrolo[3,4-b]pyrrol-2-yl)methylene)indolin2-one (8). Yield: 50\%, pale orange solids. Mp: 167-168 ${ }^{\circ} \mathrm{C}$. UV $\lambda_{\max }(\mathrm{MeOH}), \mathrm{nm}(\log \varepsilon): 390$ (4.12), 
IR (ATR), $\mathrm{cm}^{-1}: 3172,1651,1568 .{ }^{1} \mathrm{H}-\mathrm{NMR}\left(400 \mathrm{MHz}\right.$, acetic acid- $\left.d_{4}\right) \delta$, ppm: $7.75(\mathrm{~s}, 1 \mathrm{H},-\mathrm{C}=\mathrm{CH}-)$, $7.73(\mathrm{~d}, 1 \mathrm{H}, J=7.6 \mathrm{~Hz}, \mathrm{ArH}), 7.18(\mathrm{dd}, 1 \mathrm{H}, J=7.6,7.6 \mathrm{~Hz}, \mathrm{ArH}), 7.03(\mathrm{dd}, 1 \mathrm{H}, J=7.6,7.6 \mathrm{~Hz}, \mathrm{ArH})$, $6.98(\mathrm{~d}, 1 \mathrm{H}, J=7.6 \mathrm{~Hz}, \mathrm{ArH}), 4.59\left(\mathrm{~s}, 2 \mathrm{H}, \mathrm{Ar}-\mathrm{CH}_{2}-\right), 3.55\left(\mathrm{t}, 2 \mathrm{H}, J=6.4 \mathrm{~Hz},-\mathrm{NCH}_{2} \mathrm{CH}_{2}-\right), 2.65(\mathrm{t}, 2 \mathrm{H}$, $\left.J=6.4 \mathrm{~Hz},-\mathrm{NCH}_{2} \mathrm{CH}_{2}-\right), 2.55\left(\mathrm{q}, 4 \mathrm{H}, J=7.2 \mathrm{~Hz},-\mathrm{N}\left(\mathrm{CH}_{2} \mathrm{CH}_{3}\right)_{2}\right), 2.47\left(\mathrm{~s}, 3 \mathrm{H}, \mathrm{Ar}-\mathrm{CH}_{3}\right), 0.99(\mathrm{t}, 6 \mathrm{H}$, $\left.J=7.2 \mathrm{~Hz},-\mathrm{N}\left(\mathrm{CH}_{2} \mathrm{CH}_{3}\right)_{2}\right),{ }^{13} \mathrm{C}-\mathrm{NMR}\left(100 \mathrm{MHz}\right.$, acetic acid- $\left.d_{4}\right) \delta$, ppm: $171.5,170.0,149.6,139.3,133.6$, 126.3, 126.0, 125.2, 123.4, 120.9, 119.6, 118.6, 111.4, 51.9, 48.6, 48.2, 39.6, 9.9, 8.8. HRMS m/z (ESI): calcd., $379.2129[\mathrm{M}+\mathrm{H}]^{+}$, found, $379.2133[\mathrm{M}+\mathrm{H}]^{+}$.

(Z)-3-((5-(2-(Diethylamino)ethyl)-3-methyl-4-oxo-1,4,5,6-tetrahydropyrrolo[3,4-b]pyrrol-2-yl)methylene)-5fluoroindolin-2-one (9). Yield: 56\%, orange solids. Mp: 245-246 ${ }^{\circ} \mathrm{C}, \mathrm{UV} \lambda_{\max }(\mathrm{MeOH}), \mathrm{nm}(\log \varepsilon): 291$ (4.33). IR (ATR), $\mathrm{cm}^{-1}: 3534,3400,1668,1572 \mathrm{~cm}^{-1} .{ }^{1} \mathrm{H}-\mathrm{NMR}\left(400 \mathrm{MHz}\right.$, acetic acid- $\left.d_{4}\right) \delta$, ppm: 7.62 $(\mathrm{s}, 1 \mathrm{H},-\mathrm{C}=\mathrm{CH}-), 7.38(\mathrm{dd}, 1 \mathrm{H}, J=9.0,2.0 \mathrm{~Hz}, \mathrm{ArH}), 6.96-6.90(\mathrm{~m}, 2 \mathrm{H}, \mathrm{ArH} \times 2), 4.59\left(\mathrm{~s}, 2 \mathrm{H}, \mathrm{Ar}-\mathrm{CH}_{2}-\right)$, $3.97\left(\mathrm{t}, 2 \mathrm{H}, J=6.0 \mathrm{~Hz},-\mathrm{NCH}_{2} \mathrm{CH}_{2}-\right), 3.49\left(\mathrm{t}, 2 \mathrm{H}, J=6.0 \mathrm{~Hz},-\mathrm{NCH}_{2} \mathrm{CH}_{2}-\right), 3.37(\mathrm{q}, 4 \mathrm{H}, J=7.2 \mathrm{~Hz}$, $\left.-\mathrm{N}\left(\mathrm{CH}_{2} \mathrm{CH}_{3}\right)_{2}\right), 2.47\left(\mathrm{~s}, 3 \mathrm{H}, \mathrm{Ar}-\mathrm{CH}_{3}\right), 1.31\left(\mathrm{t}, 6 \mathrm{H}, \mathrm{J}=7.2 \mathrm{~Hz},-\mathrm{N}\left(\mathrm{CH}_{2} \mathrm{CH}_{3}\right)_{2}\right) .{ }^{13} \mathrm{C}-\mathrm{NMR}(100 \mathrm{MHz}$, acetic acid- $\left.d_{4}\right) \delta$, ppm: 169.8, 166.1, 158.6, 148.3, 135.5, 132.4, 127.1, 125.9, 125.0, 121.0, 117.1, 113.7, 110.7, 107.0, 49.0, 46.7, 46.6, 37.3, 10.0, 8.7. HRMS m/z (ESI): calcd., $397.2034[\mathrm{M}+\mathrm{H}]^{+}$; found, $397.2038[\mathrm{M}+\mathrm{H}]^{+}$.

(Z)-5-Chloro-3-((5-(2-(diethylamino)ethyl)-3-methyl-4-oxo-1,4,5,6-tetrahydropyrrolo[3,4-b]pyrrol-2-yl) methylene)indolin-2-one (10). Yield: $54 \%$, orange solids. Mp: $252-253{ }^{\circ} \mathrm{C}, \mathrm{UV} \lambda_{\max }(\mathrm{MeOH}), \mathrm{nm}(\log \varepsilon)$ : 393 (4.37). IR (ATR), $\mathrm{cm}^{-1}: 3162,1634,1582 \mathrm{~cm}^{-1} .{ }^{1} \mathrm{H}-\mathrm{NMR}\left(400 \mathrm{MHz}\right.$, acetic acid $\left.-d_{4}\right) \delta$, ppm: 7.64 $(\mathrm{s}, 1 \mathrm{H},-\mathrm{C}=\mathrm{CH}-), 7.62(\mathrm{~d}, 1 \mathrm{H}, J=2.0 \mathrm{~Hz}, \operatorname{ArH}), 7.16(\mathrm{dd}, 1 \mathrm{H}, J=8.2,2.0 \mathrm{~Hz}, \mathrm{ArH}), 6.96(\mathrm{~d}, 1 \mathrm{H}, J=8.2 \mathrm{~Hz}$, $\mathrm{ArH}), 4.59\left(\mathrm{~s}, 2 \mathrm{H}, \mathrm{Ar}-\mathrm{CH}_{2}\right), 3.97\left(\mathrm{t}, 2 \mathrm{H}, J=6.0 \mathrm{~Hz}, \mathrm{NCH}_{2} \mathrm{CH}_{2}-\right), 3.49\left(\mathrm{t}, 2 \mathrm{H}, J=6.0 \mathrm{~Hz},-\mathrm{NCH}_{2} \mathrm{CH}_{2}-\right)$, $3.37\left(\mathrm{q}, 4 \mathrm{H}, J=7.2 \mathrm{~Hz},-\mathrm{N}\left(\mathrm{CH}_{2} \mathrm{CH}_{3}\right)_{2}\right), 2.47\left(\mathrm{~s}, 3 \mathrm{H}, \mathrm{Ar}-\mathrm{CH}_{3}\right), 1.31\left(\mathrm{t}, 6 \mathrm{H}, J=7.2 \mathrm{~Hz},-\mathrm{N}\left(\mathrm{CH}_{2} \mathrm{CH}_{3}\right)_{2}\right)$. ${ }^{13} \mathrm{C}-\mathrm{NMR}\left(100 \mathrm{MHz}\right.$, acetic acid- $\left.d_{4}\right) \delta$, ppm: 171.2, 169.7, 149.9, 137.7, 133.6, 128.6, 128.5, 127.9, 127.4, 126.6, 121.1, 119.6, 117.2, 112.5, 51.8, 48.6, 48.1, 39.5, 9.9, 8.7. HRMS m/z (ESI): calcd., $413.1744[\mathrm{M}+\mathrm{H}]^{+}$; found, $413.1743[\mathrm{M}+\mathrm{H}]^{+}$.

(Z)-5-Bromo-3-((5-(2-(diethylamino)ethyl)-3-methyl-4-oxo-1,4,5,6-tetrahydropyrrolo[3,4-b]pyrrol-2-yl) methylene)indolin-2-one (11). Yield: $56 \%$, orange solids. Mp: $266-267^{\circ} \mathrm{C}$. UV $\lambda_{\max }(\mathrm{MeOH}), \mathrm{nm}(\log \varepsilon)$ : 394 (4.56), IR (ATR), $\mathrm{cm}^{-1}: 3161,1634,1581 \mathrm{~cm}^{-1} .{ }^{1} \mathrm{H}-\mathrm{NMR}\left(400 \mathrm{MHz}\right.$, acetic acid $\left.-d_{4}\right) \delta$, ppm: 7.74 $(\mathrm{d}, 1 \mathrm{H}, J=1.6 \mathrm{~Hz}, \mathrm{ArH}), 7.59(\mathrm{~s}, 1 \mathrm{H},-\mathrm{C}=\mathrm{CH}-), 7.30(\mathrm{dd}, 1 \mathrm{H}, J=8.4,1.6 \mathrm{~Hz}, \mathrm{ArH}), 6.90(\mathrm{~d}, 1 \mathrm{H}, J=8.4 \mathrm{~Hz}$, $\mathrm{ArH}), 4.55\left(\mathrm{~s}, 2 \mathrm{H}, \mathrm{Ar}-\mathrm{CH}_{2}-\right), 3.96\left(\mathrm{t}, 2 \mathrm{H}, J=6.0 \mathrm{~Hz},-\mathrm{NCH}_{2} \mathrm{CH}_{2}-\right), 3.50\left(\mathrm{t}, 2 \mathrm{H}, J=6.0 \mathrm{~Hz},-\mathrm{NCH}_{2} \mathrm{CH}_{2}-\right)$, $3.38\left(\mathrm{q}, 4 \mathrm{H}, J=7.2 \mathrm{~Hz},-\mathrm{N}\left(\mathrm{CH}_{2} \mathrm{CH}_{3}\right)_{2}\right), 2.46\left(\mathrm{~s}, 3 \mathrm{H}, \mathrm{Ar}-\mathrm{CH}_{3}\right), 1.33\left(\mathrm{t}, 6 \mathrm{H}, J=7.2 \mathrm{~Hz},-\mathrm{N}\left(\mathrm{CH}_{2} \mathrm{CH}_{3}\right)_{2}\right)$. ${ }^{13} \mathrm{C}-\mathrm{NMR}\left(100 \mathrm{MHz}\right.$, acetic acid- $\left.d_{4}\right) \delta$, ppm: 171.0, 169.6, 149.8, 138.0, 133.6, 130.7, 128.4, 127.3, 126.4, 122.4, 121.1, 117.0, 115.8, 112.9, 51.8, 48.5, 48.1, 39.5, 9.9, 8.7. HRMS m/z (ESI): calcd., 457.1239 [M + H] $]^{+}$; found, $457.1236[\mathrm{M}+\mathrm{H}]^{+}$.

(Z)-3-((5-(2-(Diethylamino)ethyl)-3-methyl-4-oxo-1,4,5,6-tetrahydropyrrolo[3,4-b]pyrrol-2-yl)methylene)-5iodoindolin-2-one (12). Yield: $43 \%$, brown solids, Mp: $267-268{ }^{\circ} \mathrm{C}$. UV $\lambda_{\max }(\mathrm{MeOH}), \mathrm{nm}(\log \varepsilon): 394$ (4.36), IR (ATR), $\mathrm{cm}^{-1}: 3174,1689,1584 \mathrm{~cm}^{-1}$. ${ }^{1} \mathrm{H}-\mathrm{NMR}\left(400 \mathrm{MHz}\right.$, acetic acid $\left.-d_{4}\right) \delta$, ppm: 7.94 $(\mathrm{s}, 1 \mathrm{H},-\mathrm{C}=\mathrm{CH}), 7.64(\mathrm{~s}, 1 \mathrm{H}, \mathrm{ArH}), 7.50(\mathrm{~d}, 1 \mathrm{H}, J=8.0 \mathrm{~Hz}, \mathrm{ArH}), 6.81(\mathrm{~d}, 1 \mathrm{H}, J=8.0 \mathrm{~Hz}, \mathrm{ArH}), 4.59$ $\left(\mathrm{s}, 2 \mathrm{H}, \mathrm{Ar}-\mathrm{CH}_{2}-\right), 3.97\left(\mathrm{t}, 2 \mathrm{H}, J=6.0 \mathrm{~Hz},-\mathrm{NCH}_{2} \mathrm{CH}_{2}-\right), 3.49\left(\mathrm{t}, 2 \mathrm{H}, J=6.0 \mathrm{~Hz},-\mathrm{NCH}_{2} \mathrm{CH}_{2}-\right), 3.37(\mathrm{q}, 4 \mathrm{H}$, $\left.J=7.2 \mathrm{~Hz},-\mathrm{N}\left(\mathrm{CH}_{2} \mathrm{CH}_{3}\right)_{2}\right), 2.47\left(\mathrm{~s}, 3 \mathrm{H}, \mathrm{Ar}-\mathrm{CH}_{3}\right), 1.31\left(\mathrm{t}, 6 \mathrm{H}, J=7.2 \mathrm{~Hz},-\mathrm{N}\left(\mathrm{CH}_{2} \mathrm{CH}_{3}\right)_{2}\right) .{ }^{13} \mathrm{C}-\mathrm{NMR}$ $\left(100 \mathrm{MHz}\right.$, acetic acid- $\left.d_{4}\right) \delta$, ppm: 171.6, 169.8, 149.9, 149.9, 149.8, 133.5, 127.5, 126.5, 121.1, 116.1, 114.6, 112.2, 112.1, 106.7, 51.6, 49.4, 48.2, 39.5, 9.9, 8.8. HRMS $m / z$ (ESI): $505.1100[\mathrm{M}+\mathrm{H}]^{+}$; found, 505.1094 $[\mathrm{M}+\mathrm{H}]^{+}$.

\subsection{Biology}

\subsubsection{Cell Culture}

The HCT116 (human colon cancer cells, BCRC 60349) and Detroit 551 (human normal fibroblast cells, BCRC 60118) were maintained in DMEM (Gibco, Grand Island, NY, USA) containing 10\% FBS (HyClone, Logan, UT, USA). NCI-H460 (BCRC 60373) and 786-O (BCRC 60243) were maintained in 
RPMI 1640 (Gibco, Grand Island, NY, USA) containing 10\% FBS (HyClone, Logan, UT, USA). They were incubated at $37^{\circ} \mathrm{C}$ in a $5 \% \mathrm{CO}_{2}$ atmosphere.

\subsubsection{Cell Proliferation Assay}

The cells incubated as above were plated at a density of 2000 cells/well (cancer cells) [18,41,42] or 10,000 cells/well (Detroit 551) on a 96-well plate for $24 \mathrm{~h}$; serial dilutions of indicated compounds were added and incubated for additional $72 \mathrm{~h}$. At the end of the incubation, cell viability was determined by 3-(4,5-dimethylthiazol-2-yl)-2,5-diphenyl tetrazolium bromide (MTT). The MTT formazan crystals were dissolved by DMSO, and the absorbance at $570 \mathrm{~nm}$ using a microplate spectrophotometer (Thermo Fisher Scientific, Waltham, MA, USA) [43].

\subsubsection{Acute Cytotoxicity}

The acute cytotoxicity effect of sunitinib and compounds 8-12 was determined by Cell-Counting-Kit-8 (Dojindo, Rockville, MD, USA) assay on HCT116, NCI-460, 786-O and Detroit 551 with the manufacturer's protocol. Cells were seeded at 5000 cells/well on a 96-well plate for $24 \mathrm{~h}$. The indicated compounds in different concentration $(100 \mu \mathrm{L})$ were added to cells. Post $6 \mathrm{~h}$, old medium was aspirated, and cells were washed three times with PBS. WST-8 (Dojindo, Rockville, MD, USA) $(10 \mu \mathrm{L})$ was added to each well, and the absorbance of the plate was recorded at $450 \mathrm{~nm}$ on a microplate spectrophotometer (Thermo Fisher Scientific, Waltham, MA, USA).

\subsubsection{Image Cytometry}

Cell cycle profiles of HCT116 cells were determined with an NC-3000 image cytometer (ChemoMetec, Allerod, Denmark) in accordance with manufacturer's protocol. Briefly, cells were seeded at 200,000 cells/well on a 6-well plate for $24 \mathrm{~h}$. $2 \mathrm{~mL}$ of indicated compounds $(5.0 \mu \mathrm{M}$ for sunitinib and 8-10, $1.0 \mu \mathrm{M}$ for $\mathbf{1 1}$ and 12) were added to cells. After incubation for $24 \mathrm{~h}, 100,000$ cells were harvested and centrifuged for $5 \mathrm{~min}$ at $400 \mathrm{~g}$ at room temperature, washed once with PBS $(50 \mu \mathrm{M})$ and resuspended with $50 \mu \mathrm{L}$ of lysis buffer (ChemoMetec, Allerod, Denmark) containing $10 \mu \mathrm{g} / \mathrm{mL}$ of 2-(4-amidinophenyl)-1H-indole-6-carboxamidine (DAPI, ChemoMetec, Allerod, Denmark). The cells were incubated at $37^{\circ} \mathrm{C}$ for $5 \mathrm{~min}, 50 \mu \mathrm{L}$ of stabilization buffer (ChemoMetec, Allerod, Denmark) was added to the solution, and the cellular fluorescence was measured with an NC-3000 image cytometer using NC-SlideA8 (ChemoMetec, Allerod, Denmark). The NC-3000 software (ChemoMetec, Allerod, Denmark) was used for image acquisition, image analysis and quantification and data visualization.

\subsubsection{In Vitro Tube Formation Assay}

Angiogenesis Kit (Kurabo, Neyagawa, Osaka, Japan) was used in accordance with the manufacturer's protocols. Briefly, HUVECs and fibroblasts were co-cultured in 24-well plates with basal medium or solvent control medium (basal medium containing 1.0\% DMSO) or solvent control medium containing 9, 10, 11, and $12(0.50 \mu \mathrm{M}, 0.25 \mu \mathrm{M}$ and $0.10 \mu \mathrm{M})$. The medium renewals with or without agent in cultures were conducted every 3 days. After 11 days HUVECs were fixed and stained with anti-CD31 antibody in line with the manufacturer's protocols. The tube formation area were measured using Angiogenesis Image Analyzer (Kurabo, Neyagawa, Osaka, Japan) with suaramin $(70 \mu \mathrm{M})$ as positive control.

\subsubsection{In Vitro Kinase Assay}

The Reaction Biology Corporation (http:/ / www.reactionbiology.com) HotSpot assay platform was used to determine the inhibitory activity of compounds 8-12 and sunitinib against VEGFR-2, PDGFR and aurora A, which was measured by quantifying the amount of $33 \mathrm{P}$ incorporated into the substrate in the presence of the test compound [44]. Briefly, specific kinase and substrate and required cofactors were prepared in reaction buffer. Test compounds were added into the reaction, after $20 \mathrm{~min}$, 
a mixture of ATP (Sigma, St. Louis, MO, USA) and ${ }^{33} \mathrm{P}$ ATP (Perkin Elmer, Waltham, MA, USA) was added to make a final concentration of $10.0 \mu \mathrm{M}$. Reactions were stood at room temperature for $120 \mathrm{~min}$, and spot the reactions onto P81 ion exchange filter paper (Whatman Inc., Piscataway, NJ, USA). Unbound phosphate was removed by extensive washing of filters in $0.1 \%$ phosphoric acid. Kinase activity data was reported as the percent remaining kinase activity in test compounds compared to solvent control (DMSO).

\subsection{Molecular Modeling}

Ligands-receptor docking calculation was carried out using the LibDock protocol. Briefly, receptor active site and ligands were characterized into polar and apolar hotspots. The ligand poses were placed into the receptor site by hotspots accordance. In this study CHARMm force field was used for energy minimization of the ligand molecules and ligand-receptor binding. The binding sphere was defined based on the PDB definition. Conformations of ligands were generated by the BEST method. The LibDock score was scored by default settings including Ligscore, PLP, Jain, PMF and PMF04.

\subsection{Statistical Analysis}

Statistical calculations were carried out with GraphPad Prism version 5. Results were reported as the mean \pm SD. Statistical significance was determined by the unpaired student's $t$ test.

\section{Conclusions}

A series of novel $N$-substituted 2-pyrrolidone fused (2-oxoindolin-3-ylidene)methylpyrrole derivatives 8-12 were successfully prepared and examined for their anti-tumor activities. Several of them significantly improved inhibitory activity against VEGFR-2 and PDGFR $\beta$ over sunitinib. Compared to sunitinib, all our synthetic compounds showed a similar but tighter binding mode with VEGFR-2. The nature of $C(5)$ halogens and the rigid conformation of the scaffold obviously were important determinants of both enzymatic and cellular anti-tumor activities. Among the products obtained, 11 (C(5)-Br) and 12 (C(5)-I) consistently displayed the most potent and favorable selective indexes and might be promising to be used as novel anti-angiogenic agents in the targeted therapy of cancer. The results gleaned from this investigation have important potential applications in the development of new anticancer drugs.

Acknowledgments: The authors would like to thank the Ministry of Science and Technology, R.O.C. for financially supporting this research under Contract No. NSC-104-2320-B-016-004.

Author Contributions: T.-H.Y., C.-I.L., W.-H.H., and A.-R.L. conceived, designed, performed the experiments; analyzed the data; contributed the reagents/materials/analysis tools; wrote; approved the final manuscript.

Conflicts of Interest: The authors declare no conflict of interest. The founding sponsors had no role in the design of the study; in the collection, analyses, or interpretation of data; in the writing of the manuscript, and in the decision to publish the results.

\section{References}

1. Felmeden, D.C.; Blann, A.D.; Lip, G.Y. Angiogenesis: Basic pathophysiology and implications for disease. Eur. Heart J. 2003, 24, 586-603. [CrossRef]

2. Hanahan, D.; Weinberg, R.A. Hallmarks of cancer: The next generation. Cell 2011, 144, 646-674. [CrossRef] [PubMed]

3. Folkman, J. Tumor angiogenesis: Therapeutic implications. N. Engl. J. Med. 1971, 285, 1182-1186. [PubMed]

4. Roskoski, R., Jr. Sunitinib: A vegf and pdgf receptor protein kinase and angiogenesis inhibitor. Biochem. Biophys. Res. Commun. 2007, 356, 323-328. [CrossRef] [PubMed]

5. Cristofanilli, M.; Charnsangavej, C.; Hortobagyi, G.N. Angiogenesis modulation in cancer research: Novel clinical approaches. Nat. Rev. Drug Discov. 2002, 1, 415-426. [CrossRef] [PubMed] 
6. Chouhan, J.D.; Zamarripa, D.E.; Lai, P.H.; Oramasionwu, C.U.; Grabinski, J.L. Sunitinib (sutent): A novel agent for the treatment of metastatic renal cell carcinoma. J. Oncol. Pharm. Pract. 2007, 13, 5-15. [CrossRef] [PubMed]

7. Chen, J.; Zhou, W.; Jia, Q.; Chen, J.; Zhang, S.; Yao, W.; Wei, F.; Zhang, Y.; Yang, F.; Huang, W.; et al. Efficient extravasation of tumor-repopulating cells depends on cell deformability. Sci. Rep. 2016, 6, 19304. [CrossRef] [PubMed]

8. Jin, Z.H.; Furukawa, T.; Claron, M.; Boturyn, D.; Coll, J.L.; Fukumura, T.; Fujibayashi, Y.; Dumy, P.; Saga, T. Positron emission tomography imaging of tumor angiogenesis and monitoring of antiangiogenic efficacy using the novel tetrameric peptide probe ${ }^{64} \mathrm{Cu}$-cyclam-RAFT-c(-RGDfK-) 4 . Angiogenesis 2012, 15, 569-580. [CrossRef] [PubMed]

9. Fong, T.A.; Shawver, L.K.; Sun, L.; Tang, C.; App, H.; Powell, T.J.; Kim, Y.H.; Schreck, R.; Wang, X.; Risau, W.; et al. Su5416 is a potent and selective inhibitor of the vascular endothelial growth factor receptor (Flk-1/KDR) that inhibits tyrosine kinase catalysis, tumor vascularization, and growth of multiple tumor types. Cancer Res. 1999, 59, 99-106. [PubMed]

10. Scagliotti, G.; Govindan, R. Targeting angiogenesis with multitargeted tyrosine kinase inhibitors in the treatment of non-small cell lung cancer. Oncologist 2010, 15, 436-446. [CrossRef] [PubMed]

11. Godl, K.; Gruss, O.J.; Eickhoff, J.; Wissing, J.; Blencke, S.; Weber, M.; Degen, H.; Brehmer, D.; Orfi, L.; Horvath, Z.; et al. Proteomic characterization of the angiogenesis inhibitor SU6668 reveals multiple impacts on cellular kinase signaling. Cancer Res. 2005, 65, 6919-6926. [CrossRef] [PubMed]

12. Kogan, M.; Fischer-Smith, T.; Kaminsky, R.; Lehmicke, G.; Rappaport, J. CSF-1R up-regulation is associated with response to pharmacotherapy targeting tyrosine kinase activity in amL cell lines. Anticancer Res. 2012, 32, 893-899. [PubMed]

13. Jeong, W.J.; Mo, J.H.; Park, M.W.; Choi, I.J.; An, S.Y.; Jeon, E.H.; Ahn, S.H. Sunitinib inhibits papillary thyroid carcinoma with RET/PTC rearrangement but not braf mutation. Cancer Biol. Ther. 2011, 12, 458-465. [CrossRef] [PubMed]

14. Rock, E.P.; Goodman, V.; Jiang, J.X.; Mahjoob, K.; Verbois, S.L.; Morse, D.; Dagher, R.; Justice, R.; Pazdur, R. Food and drug administration drug approval summary: Sunitinib malate for the treatment of gastrointestinal stromal tumor and advanced renal cell carcinoma. Oncologist 2007, 12, 107-113. [CrossRef] [PubMed]

15. Sun, L.; Tran, N.; Liang, C.; Hubbard, S.; Tang, F.; Lipson, K.; Schreck, R.; Zhou, Y.; McMahon, G.; Tang, C. Identification of substituted 3-[(4,5,6,7-tetrahydro-1H-indol-2-yl)methylene]-1,3-dihydroindol-2-ones as growth factor receptor inhibitors for VEGF-R2 (Flk-1/KDR), FGF-R1, and PDGF-R $\beta$ tyrosine kinases. J. Med. Chem. 2000, 43, 2655-2663. [CrossRef] [PubMed]

16. Sun, L.; Liang, C.; Shirazian, S.; Zhou, Y.; Miller, T.; Cui, J.; Fukuda, J.Y.; Chu, J.Y.; Nematalla, A.; Wang, X.; et al. Discovery of 5-[5-fluoro-2-oxo-1,2-dihydroindol-(3Z)-ylidenemethyl]-2,4dimethyl-1H-pyrrole-3-carboxylic acid (2-diethylaminoethyl)amide, a novel tyrosine kinase inhibitor targeting vascular endothelial and platelet-derived growth factor receptor tyrosine kinase. J. Med. Chem. 2003, 46, 1116-1119. [PubMed]

17. Kammasud, N.; Boonyarat, C.; Sanphanya, K.; Utsintong, M.; Tsunoda, S.; Sakurai, H.; Saiki, I.; Andre, I.; Grierson, D.S.; Vajragupta, O. 5-Substituted pyrido[2,3- $d$ ]pyrimidine, an inhibitor against three receptor tyrosine kinases. Bioorg. Med. Chem. Lett. 2009, 19, 745-750. [CrossRef] [PubMed]

18. Chiang, C.C.; Lin, Y.H.; Lin, S.F.; Lai, C.L.; Liu, C.; Wei, W.Y.; Yang, S.C.; Wang, R.W.; Teng, L.W.; Chuang, S.H.; et al. Discovery of pyrrole-indoline-2-ones as aurora kinase inhibitors with a different inhibition profile. J. Med. Chem. 2010, 53, 5929-5941. [CrossRef] [PubMed]

19. Cho, T.P.; Dong, S.Y.; Jun, F.; Hong, F.J.; Liang, Y.J.; Lu, X.; Hua, P.J.; Li, L.Y.; Lei, Z.; Bing, H.; et al. Novel potent orally active multitargeted receptor tyrosine kinase inhibitors: Synthesis, structure-activity relationships, and antitumor activities of 2-indolinone derivatives. J. Med. Chem. 2010, 53, 8140-8149. [PubMed]

20. Zhang, J.; Yang, P.L.; Gray, N.S. Targeting cancer with small molecule kinase inhibitors. Nat. Rev. Cancer 2009, 9, 28-39. [CrossRef] [PubMed]

21. Wu, P.; Nielsen, T.E.; Clausen, M.H. Fda-approved small-molecule kinase inhibitors. Trends Pharmacol. Sci. 2015, 36, 422-439. [CrossRef] [PubMed] 
22. Gajiwala, K.S.; Wu, J.C.; Christensen, J.; Deshmukh, G.D.; Diehl, W.; DiNitto, J.P.; English, J.M.; Greig, M.J.; He, Y.A.; Jacques, S.L.; et al. Kit kinase mutants show unique mechanisms of drug resistance to imatinib and sunitinib in gastrointestinal stromal tumor patients. Proc. Natl. Acad. Sci. USA 2009, 106, 1542-1547. [CrossRef] [PubMed]

23. Gao, J.; Ha, B.H.; Lou, H.J.; Morse, E.M.; Zhang, R.; Calderwood, D.A.; Turk, B.E.; Boggon, T.J. Substrate and inhibitor specificity of the type II p21-activated kinase, PAK6. PLoS ONE 2013, 8, e77818. [CrossRef] [PubMed]

24. Kennedy, D.P.; Kormos, C.M.; Burdette, S.C. Ferribright: A rationally designed fluorescent probe for redox active metals. J. Am. Chem. Soc. 2009, 131, 8578-8586. [CrossRef] [PubMed]

25. Cho, B.T.; Kang, S.K. Direct and indirect reductive amination of aldehydes and ketones with solid acid-activated sodium borohydride under solvent-free conditions. Tetrahedron 2005, 61, 5725-5734. [CrossRef]

26. Li, J.; Subramaniam, K.; Smith, D.; Qiao, J.X.; Li, J.J.; Qian-Cutrone, J.; Kadow, J.F.; Vite, G.D.; Chen, B.-C. $\mathrm{AlMe}_{3}$-promoted formation of amides from acids and amines. Org. Lett. 2012, 14, 214-217. [CrossRef] [PubMed]

27. Novak, A.; Humphreys, L.D.; Walker, M.D.; Woodward, S. Amide bond formation using an air-stable source of $\mathrm{AlMe}_{3}$. Tetrahedron Lett. 2006, 47, 5767-5769. [CrossRef]

28. Basha, A.; Lipton, M.; Weinreb, S.M. A mild, general method for conversion of esters to amides. Tetrahedron Lett. 1977, 18, 4171-4172. [CrossRef]

29. Dubois, N.; Glynn, D.; McInally, T.; Rhodes, B.; Woodward, S.; Irvine, D.J.; Dodds, C. On DABAL-Me 3 promoted formation of amides. Tetrahedron 2013, 69, 9890-9897. [CrossRef]

30. Kuchar, M.; Oliveira, M.C.; Gano, L.; Santos, I.; Kniess, T. Radioiodinated sunitinib as a potential radiotracer for imaging angiogenesis-radiosynthesis and first radiopharmacological evaluation of 5-[ ${ }^{125}$ i]iodo-sunitinib. Bioorg. Med. Chem. Lett. 2012, 22, 2850-2855. [CrossRef] [PubMed]

31. Jin, Y.Z.; Fu, D.X.; Ma, N.; Li, Z.C.; Liu, Q.H.; Xiao, L.; Zhang, R.H. Synthesis and biological evaluation of 3-substituted-indolin-2-one derivatives containing chloropyrrole moieties. Molecules 2011, 16, 9368-9385. [CrossRef] [PubMed]

32. Chen, D.; Wei, L.; Yu, J.; Zhang, L. Regorafenib inhibits colorectal tumor growth through PUMA-mediated apoptosis. Clin. Cancer Res. 2014, 20, 3472-3484. [CrossRef] [PubMed]

33. Zheng, X.; He, K.; Zhang, L.; Yu, J. Crizotinib induces puma-dependent apoptosis in colon cancer cells. Mol. Cancer Ther. 2013, 12, 777-786. [CrossRef] [PubMed]

34. Dudgeon, C.; Peng, R.; Wang, P.; Sebastiani, A.; Yu, J.; Zhang, L. Inhibiting oncogenic signaling by sorafenib activates PUMA via GSK3 $\beta$ and NF-KB to suppress tumor cell growth. Oncogene 2012, 31, 4848-4858. [CrossRef] [PubMed]

35. Sun, J.; Sun, Q.; Brown, M.F.; Dudgeon, C.; Chandler, J.; Xu, X.; Shu, Y.; Zhang, L.; Yu, J. The multi-targeted kinase inhibitor sunitinib induces apoptosis in colon cancer cells via PUMA. PLoS ONE 2012, 7, e43158.

36. Sun, J.; Knickelbein, K.; He, K.; Chen, D.; Dudgeon, C.; Shu, Y.; Yu, J.; Zhang, L. Aurora kinase inhibition induces puma via NF-kB to kill colon cancer cells. Mol. Cancer Ther. 2014, 13, 1298-1308. [CrossRef] [PubMed]

37. Fancelli, D.; Berta, D.; Bindi, S.; Cameron, A.; Cappella, P.; Carpinelli, P.; Catana, C.; Forte, B.; Giordano, P.; Giorgini, M.L.; et al. Potent and selective aurora inhibitors identified by the expansion of a novel scaffold for protein kinase inhibition. J. Med. Chem. 2005, 48, 3080-3084. [CrossRef] [PubMed]

38. McTigue, M.; Murray, B.W.; Chen, J.H.; Deng, Y.L.; Solowiej, J.; Kania, R.S. Molecular conformations, interactions, and properties associated with drug efficiency and clinical performance among VEGFR TK inhibitors. Proc. Natl. Acad. Sci. USA 2012, 109, 18281-18289. [CrossRef] [PubMed]

39. Pedras, M.S.; Jha, M. Concise syntheses of the cruciferous phytoalexins brassilexin, sinalexin, wasalexins, and analogues: Expanding the scope of the vilsmeier formylation. J. Org. Chem. 2005, 70, 1828-1834. [CrossRef] [PubMed]

40. Boiadjiev, S.E.; Lightner, D.A. Readily synthesized novel fluorescent dipyrrinones. J. Org. Chem. 2005, 70, 688-691. [CrossRef] [PubMed]

41. Zhao, Y.; Yu, D.; Wu, H.; Liu, H.; Zhou, H.; Gu, R.; Zhang, R.; Zhang, S.; Wu, G. Anticancer activity of SAHA, a potent histone deacetylase inhibitor, in NCI-H460 human large-cell lung carcinoma cells in vitro and in vivo. Int. J. Oncol. 2014, 44, 451-458. [PubMed] 
42. Tomita, S.; Ishibashi, K.; Hashimoto, K.; Sugino, T.; Yanagida, T.; Kushida, N.; Shishido, K.; Aikawa, K.; Sato, Y.; Suzutani, T.; et al. Suppression of SOCS3 increases susceptibility of renal cell carcinoma to interferon- $\alpha$. Cancer Sci. 2011, 102, 57-63. [CrossRef] [PubMed]

43. Lee, S.M.; Chiang, S.H.; Wang, H.Y.; Wu, P.S.; Lin, C.C. Curcumin enhances the production of major structural components of elastic fibers, elastin, and fibrillin-1, in normal human fibroblast cells. Biosci. Biotechnol. Biochem. 2015, 79, 247-252. [CrossRef] [PubMed]

44. Anastassiadis, T.; Deacon, S.W.; Devarajan, K.; Ma, H.; Peterson, J.R. Comprehensive assay of kinase catalytic activity reveals features of kinase inhibitor selectivity. Nat. Biotechnol. 2011, 29, 1039-1045. [CrossRef] [PubMed]

Sample Availability: Not available.

(C) 2017 by the authors. Licensee MDPI, Basel, Switzerland. This article is an open access article distributed under the terms and conditions of the Creative Commons Attribution (CC BY) license (http://creativecommons.org/licenses/by/4.0/). 